\title{
ARE WE A
}

DEGLINING

RAGEP an OLO

SAILOR'S VERDIGT. BY

\section{WALTER HUNT.}

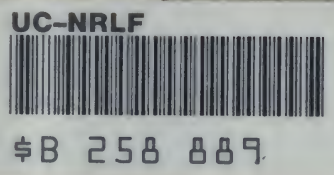

1/-NET. LONDON: FRANCIS R. HENDERSON. 

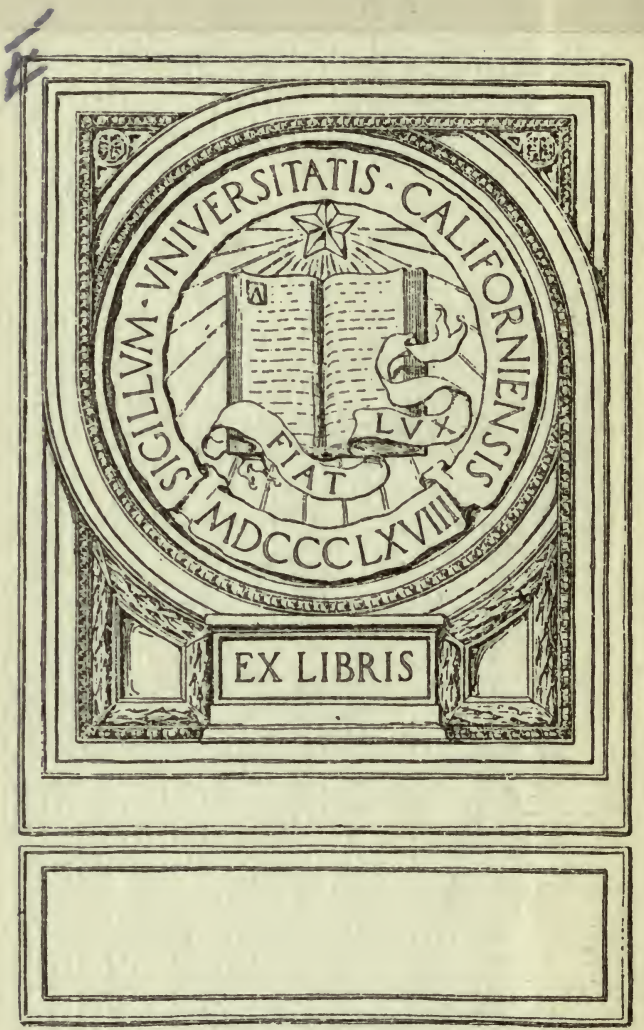
$x^{-2}-5=$

$+\frac{1}{2}$ 
Digitized by the Internet Archive in 2007 with funding from Microsoft Corporation 
ARE WE A DECLINING RACE ? 


\author{
PRINTED BY \\ Saunders and Cullingham, \\ 4, Burgon Streat, \\ Carter lane, ludgate Hill, E.C,
}




\title{
ARE WE A DECLINING
}

\section{RACE ?}

\section{AN OLD SAILOR'S VERDICT.}

\author{
BY
}

\section{WALTER HUNT.}

LONDON :

FRANCIS RIDDELL HENDERSON,

26, Paternoster Square.

1904, 
"Such is our state I in a tempestuous sea, With all the crew raging in mutiny! No duty followed, none to reef a sail, To work the ressel, or to pump or bale: All is abandoned, and without a check The mighty sea comes sweeping o'er the deck. Our steersman, hitherto so bold and steady, Active and able, is deposed already. No discipline, no sense of order felt, The daily messes are unduly dealt. The goods are plundered, those that ought to keep Strict watch are idly skulking or asleep; All that is left of order or command Committed wholly to the basest hand. In such a case, my friend, I needs must think It were no maryal though the ressel sink. This riddle to my worthy friends I tell, But a shrewd knaye will understand it well."

-Theognis. 


\section{PREFACE。}

IT is not with any pretention to literary ability that I venture to approach this all-important question, nor even with the confidence of being able to make the subject sufficiently palatable for the general public; but having had opportunities of witnessing the effects of certain habits on the physique of peoples, both in savage life and in civilised communities, also having devoted a considerable number of years to the study of the subject, I am led to hope that what I have to say, resulting from my experience and studies, may be of some value.

So far back as twenty years ago I had arrived at the startling conclusion that there was a general physical degeneration, not only in our own country-nor even limited to civilised countries-but extended over the whole world. Such a statement, if made at that time, would have met with but very few supporters. Subsequent events, however, have only more fully convinced me that I was right, both in my recognition of the fact of the general decline, and in my conclusions as to the causes which, during all historical time, have been leading up to this deplorable result.

My reasons for thinking as I do, and the connecting circumstances, are perhaps somewhat imperfectly stated, and if that be so, I ask the indulgence of the reader, at the same time urging the importance of the subject matter.

Streatham,

W. H.

\section{June I7th, I904.}




\section{CONTENTS.}

$\begin{array}{llllllll}\text { Preface } & \ldots & \ldots & \ldots & \ldots & \ldots & \ldots & \ldots \\ \text { Chapter } & \text { I.- “ } & & & & & & \end{array}$ Comparisons-Description of Diet Aboard Ship Formerly-Apparent Decline in Army-Unfitness of Would-be Recruits-Comparison with the Ancients … $\quad \cdots \quad \cdots \quad \cdots$

Chapter II.-Insanity and Alcoholism.-Evidence of Decline in Civil Life-The UnemployableIncrease in Lunacy-Longevity-HeredityThe Coming Man-Massacre of the Innocents$\begin{array}{llllll}\text { Alcoholism... } & \ldots & \ldots & \ldots & \ldots & \ldots\end{array}$

Chapter III.-Civil and Savage Life Compared.The Struggle for Existence-Civilisation v. Savagedom-Pain and Suffering-Morality of the Ancients - Education of the GreeksMatrimonial Systems - Chastity among $\begin{array}{lllllll}\text { Savages } & \ldots & \ldots & \ldots & \ldots & \ldots & \ldots\end{array}$

Chapter IV.-A Remarkable Example of Decline. - Description of the Fijians as Savages: Polygamy; Land Question; Annexation; Result of European Customs; Decline of Physique; Government Enquiry; Acknowledged Failure of Missionary Enterprise; the then Governor's Description of Native Conditions...

Chapter V.-The Cause.-Self-abuse as a Cause of Physical Degeneracy among Boys-History of the Vice-Its Influence in the Fall of NationsThe Greeks Recognise it as a Fertile Source of Disease - Hippocrates and ConsumptionEighteenth Century Writers-Its Appearance in England-Its Bearing on Lunacy and Epilepsy-Treatment of Victims-Consumption, Cancer, and other Diseases-Inebriety... ...

Chapter VI.-The Conservation of Vitality.Greatest Human Virtue-Roman EmpireSalvian and the Barbarians-The Priesthood

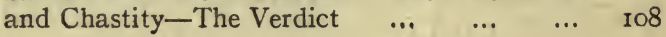

List of Principal Authorities $\quad \ldots \quad \ldots \quad \ldots$ 


\section{ARE WE A DECLINING RACE ?}

\section{AN OLD SAILOR'S VERDICT.}

\section{CHAPTER I \\ “These Degenerate Days."}

A ponderous stone bold Hector heaved to throw, Pointed above, and rough, and gross below :

Not two strong men the enormous weight could raise, Such men as live in these degenerate days.

- Homer.

THE old cry of "wolf, wolf," the complaint 1 that we are not as good as our "forebears," has been echoed from one generation to another, from time immemorial, until at last the tendency is to attach but little importance to its repetition.

To-day, however, the question of degeneration is forcing itself more and more upon our notice, and signs are not wanting that the public mind is disturbed about it. And yet the question has been for long a source of anxiety to the student of humanity. Its solution, rendered more difficult by the unnatural social conditions of our time, is of the greatest immediate importance. 


\section{Ave We a Declining Race?}

More than two thousand years ago the poet Aristophanes said of the Athenians :- "In the good old times our youths breasted the snow without a mantle, their music was masculine and martial, their gymnastic exercises decorous and chaste. Thus were trained the heroes of Marathon."

Isocrates, a great orator of the same period, said: "Thus our young men did not waste their days in the gaming houses, nor with music girls, nor in the assemblies, in which whole days are now consumed."

The Greeks learned afterwards that the reproach was only too well founded.

So it has been with Rome, with every other great nation, and so it is with us. To every successive generation, similar warnings are addressed.

The idea, in all classes of society, has frequently been made the subject of song, and in our naval service the contrast between "old navy" and "young navy" was a constant incitement to repartee.

When, at the close of the Crimean War, large numbers of men were paid off, they sang, and by all accounts with a certain amount of reason-

"They are paying off all our seamen bold, Thinking them they'll want no more, But the Navy never will be manned As it was in fifty-four."

Twenty years later, there was another clearance of a certain class of men, reckoned "undesirables."

About that time, 1874 or 1875 , several altera- 


\section{These Degenerate Days.}

tions were effected in the Navy, including a different scale of punishments, and many seamen whose characters were classed as indifferent, were not available for promotion, and were not allowed to re-engage. Not that there was any real vice in them, but merely because they did not come aboard directly their leave expired, or because they sometimes managed to get an extra " tot of grog."

Also, about that time, several ships were lost with all hands. H.M.S. Captain, in 1871, went down with about 600 men in the Bay of Biscay, H.M.S. Eurydice capsized in a snowstorm, losing all hands except three. H.M.S. Atalanta sailed away into the north Atlantic and was never again heard of ; H.M.S. Dotterel was blown up in the Straits of Magellan. About this time, too, we saw the last of the old wooden line of battleships as sea-going vessels.

This general clear-out, and the invention of a new type of vessel, in which seamanship was rendered to a certain extent unnecessary, seems to have evolved a new class of men differing in many respects from the "sea dogs" of Nelson's time. I do not say that they are an inferior class. Intellectually they are no doubt superior; for many of the old school were illiterate, which would be impossible in the Navy at the present day, as the complexity of the sailor's duties now necessitate a great deal of study.

Physically, there is no gainsaying the fact, that the men, both in the Army and Navy, have undergone a great change.

Anyone who remembers Portsmouth some 


\section{Are We a Declining Race?}

thirty years ago, when the 4 2nd "Black Watch" were stationed there, will readily acknowledge that it would be hard to find now such types of manhood as were then seen in the $42 n d$, in the Blue Marines at Eastney, and among the seamen gunners of the Excellent. Many of the latter volunteered for the Arctic Expedition that fitted out at Portsmouth in 1874 , in H.M. ships Alert and Discovery.

The rollicking, happy - go - lucky, broadshouldered, hairy-chested " Jack Tar" seems as a type to have disappeared, and we now have a more sedate, and, according to public opinion, more respectable class of men to man our "iron walls." Yet it must be borne in mind that mere " respectability" (rightly or wrongly termed such) cannot successfully replace hardihood in such a rough and ready life as that of a seaman.

Only a few months ago, I read, in Truth, that the trial trip of one of H.M. ships had to be abandoned because the greater part of the men were incapacitated through seasickness.

Shade of Nelson! This is a most alarming state of affairs if the vessel was manned by bluejackets, as seems to have been the case, for the editor of Truth, commenting on the condition of the men, hints at improper feeding as a cause.

At a matter of fact, the men are fed very much better now than they were thirty years ago. In the first place, owing to greater facilities of transport, provisions may be carried to foreign stations in better condition than formerly, and 


\section{These Degenevate Days̀.}

the food is not allowed to lie for years at foreign depôts before being used.

Then, there is the improved system of preserving meats, canning, etc., and the condensing of water. Not only this, but every ship seems to be supplied with a canteen, where all kinds of preserves may be purchased-a thing scarcely known, in a sea-going ship, in my time.

We sometimes had to exist on food that would not be considered fit to offer for sale in this country. I remember, on one occasion, that the salt pork was so exceptionally bad that we took it on the quarter-deck to protest against having to eat it. We were in the South-Western Pacific, among the "cannibal islands," at the time, and had been living on salt provisions for about eight months. The captain looked at the meat, and very logically remarked: "It certainly is very rich, but what are we to do? There is no other in the ship, so that if we pitch it overboard we shall have to starve." So we had to exist for another two months on this "rich" diet, with no change but an occasional cocoanut or a banana, when we could get them.

Here is a description of our provender: The biscuit was so far gone with the weevil and maggot that there was scarcely a piece to be found, the size of a half-crown, that was not perforated with these vermin, the greater part of it being reduced to dust. This, with a pint of cocoa, which was very ancient and had a decidedly mouldy flavour, served without milk, formed our breakfast. For dinner, there was a little variation. Every alternate day, we had 


\section{Are We a Declining Race?}

the salt pork already referred to, with some split peas added to the water in which it was boiled, making a very savoury pea soup.

Once in four days we had what was supposed to be salt beef, and plum pudding-quite a luxurious-sounding title; but one would scarcely have recognised the article under that name. The flour was often animated by the same kind of life which affected the biscuit, and the plums were few and far between. The beef was always a doubtful substance; some called it rhinoceros, but it generally went by the name of "salt horse."

Once in four days, also, we had what was then a new experiment, Australian tinned meat, with a mysterious substance called preserved potatoes, which few could eat without afterwards suffering from heartburn.

The mid-day meal was washed down by a half-gill of rum.

For supper, 4.30 p.m., we had tea, boiled in the same coppers in which the pea-soup had just previously been cooked, no milk, and another half-pound of biscuit, after which we fasted I4 hours, to allow it to digest.

This was the ordinary sea-going fare of thirty years ago, therefore if the men have had the advantage of augmenting their diet from the canteen, and the spread of civilisation with its greater facilities of transit enables them to obtain fresh provisions oftener, it is evident that the decline of physique cannot be due to the feeding. Far from objecting to an improved scale of diet, I am very glad that this is now 


\section{These Degenerate Days.}

being seen to, and that our sailors are to have better food, and more meals.

The decline is apparent in still greater degree in the army. The terrible amount of sickness and disease during the war in South Africa, from exposure, in what might be termed a moderate climate, shows the stamina of our soldiers to be very inferior.

There was a startling revelation made by Maj. Gen. Sir Frederick Maurice, K.C.B., in an article published in the Contemporary Review for January, 1903, dealing with "National Health." He wrote: "During the last seven years it has been one of my duties to visit the Herbert Hospital for the purpose of sanctioning the discharge of men who had been brought forward by a Medical Board, as no longer fit for H.M. Service. I very soon found that an alarming proportion of these men had involved the State in considerable expense, but had given no return. As soon as they were put to an average amount of work they broke down in health, had to be sent to hospital, and if after being patched up they were sent back to duty, they broke down again, and on the whole their record showed that they never had at any time become efficient soldiers.

"According to the best estimate I have been able to arrive at, it has been for many years true that out of every five men who wish to enlist and primarily offer themselves for enlistment you will find that by the end of two years' service there are only two remaining in the army as efficient soldiers. . . . 


\section{Ave We a Declining Race?}

"To me it seems a vital matter for us to enquire, what is the meaning of that disastrous proportion between the five and the two. Does it mean that the class which necessarily supplies the bulk of the ranks of our Army consists of this large proportion of men physically unfit?

"If so, what are the causes of this fatal condition of things, and are they remediable?

"It will be convenient first to record the immediate causes which seem to produce the greater number of cases of physical breakdown.

"Unquestionably heart weaknesses, pneumonia troubles, and rheumatism with its sequêlae, supply a large number. . . . Numbers of them have been unable to digest their food, on account of bad teeth. Bad teeth are also a frequent cause of rejection.

"We have to remember that the young man of 16 to 18 is what he is because of the training through which he has passed during his infancy. Therefore it is to the condition of the women and children that we must look if we have regard to the future of our land.

"The question with which I am here dealing is one about which it is vital for us to know the truth. We cannot get at it without searching investigation. . . From whom are we to get it ?

"Is it or is it not true that the whole labouring population of the land are at present living under conditions which make it impossible that they should rear the next generation to be sufficiently virile to supply more than two out 


\section{These Degenerate Days.}

of five men effective for the purposes of either peace or war?

"We want the truth.

"If by any investigation, we could ascertain the true meaning of those figures, the five and the two, which I have given, it may be that we should be able to achieve a real step towards the securing of national health and thereby to the maintaining of a virile race able to hold for us, and to hand down to our children's children, the precious heirloom which has been handed down to us by virile forefathers."

I have quoted largely from this article because I think it is all of great importance. It reveals a state of affairs which is still quite unsuspected by many. Coming from such an authority it carries all the more weight, as it is obvious that it would not be to the writer's interest or advantage to disparage the condition of the men who go to swell the ranks of the Army.

"We want the truth."

The trouble is that people are not always ready to acknowledge the truth when it is given them. The truth is easy to get in most cases, and this is as simple as most.

Since the publication of Sir Frederick Maurice's article, I have heard it stated from a public platform, by a man of some authority, that out of ro, ,oo youths who presented themselves for enlistment in Manchester, only 3,000 were accepted, and of the 3,000 accepted 2,000 were weeded out as being medically unfit. This shows us that only one in ten of those likely to 


\section{Ave We a Declining Race?}

volunteer for service in the Army, are physically fit to endure the hardships connected with a military life.

Suppose, for the sake of fairness, we take the more moderate, and perhaps more reliable statement as to the five and the two, and then refer back some two or three thousand years, and make a comparison between the soldier of to-day and the soldier of that period. Referring to the article on Sparta in the "London Encyclopædia," we read: "Till a man was thirty years old, he was not capable of serving in the army, as the best authors agree. . . . After forty years' service, a man was, by law, no longer required to go into the field, and consequently if the millitary age was thirty the Spartans were not held to be invalids till they were seventy."

What an "eye-opener" this is to us, who should have profited by the experience of the centuries which have elapsed since the age of Spartan supremacy. Many men of our time have seen the best of their lives at the age of thirty, and most men are decrepit before they reach seventy.

For the quality of the Spartan soldier one has only to refer to the battle of Thermopylæ, and for their marching abilities to the battle of Marathon. They arrived the day after the battle, having covered a distance of I 50 miles in three days. As the Spartans only employed heavy armed infantry, this was a great achievement. Their arms consisted of sword, shield, and heavy spear. As we do not read of any baggage 


\section{These Degenevate Days.}

trains accompanying these expeditions we may conclude that they carried their provisions with them, or that they had to forage for them on the way. It is not likely that the commissariat was a very extensive department with the Spartans at any time, for they were very frugal.

"The youths only were allowed to eat flesh, older men ate black broth and pulse." This does not sound very inviting; we are told that black broth was made of salt, vinegar, and blood, etc.," whatever the etcetra might be. "If they were moderate in their eating, they were in their drinking also, thirst was the sole measure thereof, and no Lacedæmonian ever thought of drinking for pleasure."

What a contrast to our twentieth century customs! It is hardly too much to say that we do nothing except for pleasure, and moderation is a virtue seldom taught.

"It was the care of Lycurgus that from their very birth the Lacedæmonians should be inured to conquer their appetites."

Surely, we shall have to learn from the ancients how to solve our problem. Moderation seems to have been the text of the wisest of their philosophers. Socrates taught that, "the victory over human habits and passion, which shall bring them into such subjection as to be subservient to the real advantage of the possessor, is that necessary virtue which philosophers denominate temperance." And thus Democritus: "To conquer one's self is the noblest victory; he is the valiant man who conquers not enemies merely, but desire." And thus Antisthenes : 


\section{Are We a Declining Race?}

"The end of philosophy is to subdue the passions, and prepare for every condition of life."

The demoralisation of that noble race had already commenced when these maxims were recorded. Luxury and indulgence were already beginning to undermine the phenomenal grandeur to which the Greeks had attained. The intellect of the Athenian, and the physique of the Spartan, were rapidly becoming absorbed by dissipations which have been detrimental to the race in all ages. 


\section{CHAPTER II.}

\section{Insanity and Alcoholism.}

"The case is hard where a good citizen,

* * * * * * * * * *

Is doomed to pay the lamentable score Of guilt accumulated long before.

* * * *

Quite undeservedly doomed to atone, In other times, for actions not his own."

-Theognis.

ThE question of deterioration does not apply only to the Army and Navy. The fact is just as evident, in civil life, as it is on the lower deck, or in the barrack room ; indeed it is noticeable in all classes of the community. From the statesman to the chimney-sweep, there seems to be the same lack of physical and mental fitness.

Critics seem to have directed the greater part of their attention to the labouring class, and yet, although it may be true that incapacity is rendered more conspicuous in those who have to depend upon physical labour for a livelihood, the percentage of physically unfit is not found to be greater in that class than in any other.

The ranks of pauperism are not necessarily recruited from the working classes alone; there are very many paupers who have never been bona-fide workers in any grade of society, but have drifted from all classes; they are the "old man of the sea" to the workers, but they no more belong to them than they do to the aristocracy 


\section{Ave We a Declining Race?}

or to the professional world. If it were possible to trace the pedigrees of these unfortunate individuals, it would be a great surprise to many who seek to wash their hands of their responsibility for them. It would be found that no professions or classes were unrepresented among them; and it is a disgrace to the country that the poor should have to bear the burdens of the very poor, or that the unemployed should be saddled with the unemployable.

By unemployable, I mean, not the incorrigibly lazy, but people who are really incapable: who, at the second or third day's work, would break down, who go to crowd the casual wards of our workhouses, and fill our hospitals and lunatic asylums. Their numbers are steadily-one might almost say rapidly-increasing.

One of the most alarming features of this problem is the marvellous increase in lunacy. Statistics issued by the London County Council for the ten years ending March 3Ist, IgoI, show an increase of nearly 50 per cent.! With regard to lunacy, the number of lunatics for which the County Council is required to find accommodation, has increased from 10,326 in I89I, to 15,5 I I in I90I, or about 50 per cent. in ten years. The total number of lunatics belonging to the County of London, including imbeciles in the workhouses on January Ist, I90I, was 21,369 .

The census for the same period showed an increase of population of about $7 \frac{1}{2}$ per cent., so that the spread of insanity is out of all proportion to the growth of population. Hereditary influences and old age are reported to be by far 


\section{Insanity and Alcoholism.}

the most prevalent predisposing causes, while drink and domestic and business troubles are the most common exciting causes.

Later statistics show that the case is getting worse. Lunacy continues to be on the increase in England and Wales. On January ist, 1903, there were 113,964 notified lunatics, being an increase of $3,25 \mathrm{I}$ on last year's number. The ratio of insane to population is a little more than 34 to 10,000 ; that is to say, one in every 293 persons is insane. This ratio has steadily increased from the year 1859 , when the proportion was 18.67 per 10,000 , or one in 536 .

What do these figures mean? Almost a cent. per cent. increase in lunacy during a little over 40 years; and the worst feature in the case is that the greater increase has taken place within the last twelve years!

Does not this mean decline? Who can view with indifference these indications of deterioration?

Yet very little is done to check the evil. We build asylums (and they are filled almost as soon as they are complete), we appoint proper attendants, and provide the patients with every nourishment. At the same time the real cause of the calamity is allowed to remain unchallenged. There are few that dare do more than hint at what might be the cause.

More than sixty years ago, Sir W. C. Ellis, then resident physician at Hanwell Asylum, cautioned the medical profession that a certain vice was a "fertile source of insanity." He said, "I have no hesitation in saying that in a very 


\section{Ave We a Declining Race?}

large number of cases, in all public asylums, the disease may be attributed to that cause."

The vice alluded to has been recognised, by the profession, as a cause of insanity, and when cases are brought under its notice medical men do all in their power to restrain the victims; but such treatment is like "locking the stable door when the steed is stolen." Knowledge on a matter of such vital importance should not remain with medical men alone; it should be public property. All parents should be able to instruct their children on such subjects, so that they may not rush blindly into the terrible pitfalls awaiting them on every hand.

Dr. R. P. Ritchie, resident surgeon at Bethnal House Asylum, published in IS6I a very instructive work on "Frequent Causes of Insanity amongst Young Men." Dr. Copland and several others have written on the subject, but these works have been written for medical reference chiefly, so that the general public has not profited much by them. This is, perhaps, where medical men are mostly to blame; they do not give us "the straight tip" on these questions; "hereditary influences and old age," are given us as being by far the most prevalent predisposing causes.

It seems strange that either of these causes should be given as very prevalent. Take old age for instance. The very fact of the average of life being lowered to about thirty-four years, indicates that we do not live to a great age; this, in itself, is evidence of decline in the race.

If any reliance is to be placed on statistics, we find that during the seventeenth and eighteenth 


\section{Insanity and Alcoholism.}

centuries people were credited with living to a much greater age than they do at present. We are bound to place a certain amount of confidence in the statements of such men as Sir John Sinclair, Dr. Fothergill, Mr. Whitehurst, etc.

Sir John Sinclair recorded a very good example of sturdy old age among the Greenwich pensioners who were living in 1802 . Ninety-five of them were over eighty years of age.

Their habits would scarcely be considered as conducive to old age. Forty-two of the ninetyfive were moderate drinkers. the remainder were in the habit of drinking freely, some of them "very freely"; fifty-nine were in the habit of chewing tobacco, while most of the others took snuff.

These men were each allowed two quarts of beer per day with their meals, so that the moderate drinkers, if they took their full rations, were in the habit of taking as much beer as to-day would make some people drunk. Those who drank freely we should probably consider as regular tipplers. One of these pensioners, John Moore, was I02 years of age, and had served thirty-one years in the Navy. According to statistics, he drank freely, chewed tobacco freely, and had four new teeth. Dr. Jameson, in commenting on the teeth, says that third teeth are commonly accounted a great mark of old age. The famous Countess of Desmond, who lived to the great age of I40 years, is said to have had a third set of teeth.

According to Easton, "On Longevity," I799, there were records of $I, 712$ centenarians during 


\section{Ave We a Declining Race?}

the seventeenth ind eighteenth centuries; of these, no less than

277 were above I ro years, \& under I 20 years of age

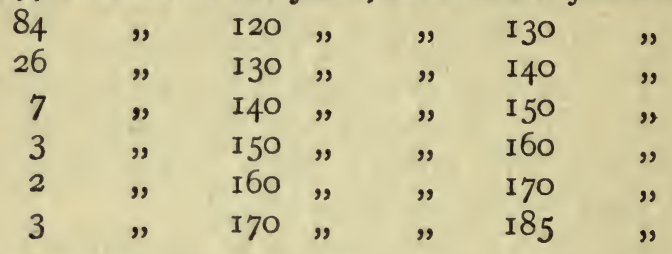

Dr. Fothergill and Mr. Whitehurst give the names of many of these people, and the counties where they resided.

To go back to an earlier date, Lord Bacon assures us, from most incontestable evidence, that in A.D. 76, when a general taxation was made over the Roman Empire by Vespasian, there were found living, in Italy, between the Appenines and the river Po, no fewer than 124 persons aged- Ioo and upwards. Of these, four were 130 , four were 136 , and three were 140 years old.

And, even on this island, things were very different to what they are now. Rapin, in the introduction to his "History of England," says : "The Britons were generally tall and well made. . . . Their constitutions were so good, that, according to Plutarch, they frequently lived I20 years. This length of days was due more to their sobriety and temperance, than to the wholesomeness of the air."

It may be objected that in the absence or uncertainty of records, these figures are unreliable. Possibly, this may be so in point of accuracy, 


\section{Insanity and Álcoholism.}

still they show that these people usually lived to a very great age.

It has also been noted of savage races that certain tribes before coming much into contact with Europeans, were of superior physique, and some lived to a great age, but that unfortunately they so soon adopt our habits and vices, that they deteriorate before we have an opportunity to study their characters.

Old age, then, can scarcely be accepted as a "most prevalent predisposing cause" of insanity. Hereditary influences may bear a more serious relation to our problem, but this only indicates that something is radically wrong in our mode of life.

Heredity seems to be using us very severely just now ; not only are maniacal and suicidal propensities transmitted to us, but our children are losing their teeth, almost as soon as they can walk, in some cases even their milk teeth decay before they are shed, and toothache may be counted as among their earliest remembrances.

Eyesight also suffers from this cause, eyesight is defective in the majority of our youth.

It would almost seem that Mr. Kay Robinson's prophesy-(Nineteenth Century, May, I883), "that the human being of the future will be a toothless, bald, toeless creature with flaccid muscles and limbs, almost incapable of locomotion," is likely to come to pass during the present century; we shall soon arrive at that state at the rate we are going. We may live to witness the disappearance of our teeth and hair, but the toes, of course, will take much longer to dis- 


\section{Are We a Declining Race?}

appear through disuse. Muscular atrophy we are certainly suffering from, as witness the unemployable, whose ranks are increasing so fast.

And after Mr. Kay Robinson's human being, what next?

The sequel to that may be found in Dr. Lister's address to the Saturday Hospital Fund meeting at the Mansion House, April 25th, I9o3.

Of every $\mathrm{I}, 000$ babies born in London, 160 do not live to the age of twelve months.

In Manchester and Liverpool it is worse, for 200 per 1,000 never live to that age, and in Berlin the alarming figure of 268 per $\mathrm{I}, 000$ is reached.

What about those who only just survive? What bright prospects for the posterity of a noble race!

Lunatic Asylums and Hospitals can scarcely be built fast enough!

According to the Annual Report of the Registrar-General, 21,039 infants under one year old died in London alone in I900; of these $\mathrm{I}, 638$ did not live three months. A great percentage of women are unable to nurse their children. One doctor states: "At the Hospital for Sick Children, go per cent. of the deaths from diarrhœa occur in hand-fed children."

How long is this massacre of innocents to last?

It will last until we resolve to return to a mode of life in which the just dues of posterity are recognised.

I have just been reading an article in the Westminster Review for September, I903, by $\mathrm{H}$. 


\section{Insanity and Alcoholism.}

Rippon Seymour, on the result of "The Royal Commission on Physical Training in Scotland, I902." It shows a most deplorable condition of health among the children, mostly those attending the Board Schools at Edinburgh, especially those of the poorer districts. The alarming discovery was made that 700 children were suffering from "unrecognised phthisis," I,300 from "unrecognised heart disease," I2,000 from " ear diseases," r 5,000 from "lesser ailments." About one-third of the children of Edinburgh were requiring immediate medical attendance.

This condition was generally ascribed to improper feeding, and want of proper physical training.

I believe our children are being fed better than they were ever fed before; we must look beyond the feeding, although that must not be neglected. Give them better food by all means, but, at the same time, let them have sound physiological instruction. Let their parents also have some physiological instruction-they need it.

It has been suggested that the children are overworked, some of them are employed out of school hours, and go to school exhausted and unfit for instruction.

Undoubtedly there are cases in which children have to work out of school hours, for the simple reason that their parents cannot afford to feed them properly unless they do something to bring in a little money. In many cases the restrictions imposed on parents make it very hard for them.

But to return to one's sheep, as the French 


\section{Are We a Declining Race?}

say. Drink is generally acknowledged as a common cause of lunacy. Many people, no doubt, would describe alcoholic excess as the principal cause.

While it cannot be denied that drink is a powerful factor in the production of insanity, it is not an independent cause. There is another element at work, which is the cause of most inebriates giving way to drink, and the same element is in itself a cause of insanity. Alcoholism is as much a result of demoralisation, as it is a cause of demoralisation, and the inebriate is not a free agent, for inebriety is itself a disease. Dr. Norman Kerr, in his work on "Inebriety," (p. I78,) gives a very plausible reason (as I shall presently show) for people giving way to alcoholism. He explains how it is that many newly-married people give way without being themselves able to understand the cause.

There has always been a certain amount of mystery about the case of the young man who, within a few months or a few years of marriage, gradually becomes a sot. From this condition he is almost irreclaimable, and in many cases it takes but a very little alcohol to keep him in a semi-intoxicated condition, because he is physically degraded. In such cases we must look beyond drink for the cause.

We frequently discover that it is possible for one man to take a great deal more alcohol and remain sober and free from its allurements, than another who might get drunk and remain a slave to its use. This shows that it is a physiological, 


\section{Insanity and Alcoholism.}

as well as a moral problem, and should be so considered. "Thus Socrates, having a clean soul in a clean body, could drink his boon companions under the table, and then go out himself and take the morning air-what was a blemish and defect in them, being simply an added power of enjoyment to himself."

It is an unfortunate thing that what might be considered as a comparatively harmless source of pleasure, should be converted into a most terrible scourge, for such in our present demoralised condition it (alcohol) proves to be.

If then, alcohol is such a curse to civilisation, why not forbid its use? If it is such a common cause of insanity, why not close the publichouses and make it illegal to sell it as a beverage? Surely this would be the easiest way out of the difficulty! Or is it too great a source of revenue, for our legislators to give it up yet? Or is it too profitable an investment, for our speculators to forego their interest in its manufacture? I am told there are many parsons, even, who are brewery shareholders, so that there is not much likelihood of our public-houses being closed just yet.

The reform must come from the people themselves. Insanity and alcoholism are the result of physical degeneration, and we must attack the cause of the degeneration before we can overcome either.

Almost as if in answer to the prophesy of $\mathrm{Mr}$. Kay Robinson two works have just appeared, both by medical men, one a Russian and the other a New Zealander, who deplore conditions 


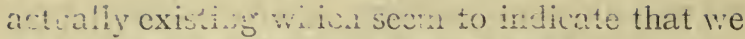
are fast approaching the state pictured by him.

Dr. V. Veresaeff assures us that:- "Our olfactory organ has become quite rudimentary; the sensibility of the cutaneous nerves to variations of temperature, and their faculty of regulating the calorification of the body, has become appreciably lessened; the glandular tissue of the female breast is becoming atrophied, considerable weakening of sexual energy is noticeable, the bones are becoming smaller, the first and the floating ribs show a tendency to disappear, the wisdom teeth have become rudimentary organs and are entirely lacked by 42 per cent. of Europeans-it is prophesied that the double molars will follow suit, the intestinal duct is ever growing briefer and the army of the bald ever increasing." ("The Confessions of a Physician," p. 2 II.)

Dr. W. A. Chapple says:- “In New Zealand the ratio of defectives, including deaf and dumb lunatics, epileptics, paralytics, crippled and deformed, debilitated and infirm, has gone from 5.4 per thousand over fifteen years, in 1874 , to $\mathrm{II}_{4} 4$ in 1896 , slightly declining to $\mathrm{IO}^{\circ} 29$ in $\mathrm{IgOI}$. The ratio of lunatics has gone up from I' 9 in I 874 to 3.4 in Igor." ("The Fertility of the Unfit.")

This would indicate that the decline is far more rapid in the salubrious climate of New Zealand even, than in this country, a fact which makes immediate investigation all the more urgent. As the title of his book implies, Dr. Chapple ascribes this condition to the indiscri- 


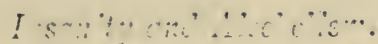

minate reprodution of the unfit. 1 he says: "Society is breeding from defective stock. The best fit to produce the best offspring are ceasing to produce their kind, while the fertility of the worst remains undisturbed," a charge which, according to the views of many, might be brought against society in most civilised countries, but, although somewhat significant, would be hardly sufficient to produce such rapid deterioration.

Dr. Veresaeff tells us further what we may expect in the near future if we continue at the present pace:- "In the same way as ordinary plain food is no more considered a suitable diet for us, so in the future will natural air become irrational, being too rare and impure for our small and delicate lungs. Man will carry an apparatus filled with concentrated pure oxygen about with him, inhaling it through a little tube, and if his apparatus suddenly goes wrong, will perish from suffocation in the free air of heaven exactly like a stranded fish. The human eye, transformed into a rudimentary and inflamed organ, will be in daily need of syringing, rinsing and cleaning. Wine, tobacco, tea, etc., losing their stimulating properties, humanity will pass on to new and more potent poisons. Fecundation will be accomplished artificially as being too gross for man, the amorous instinct finding satisfaction in voluptuous embraces and other irritants."

The doctor is not treating this matter as a huge joke, as some might be led to think; or even trying to impose on the credulity of his readers, but is seriously dealing with a very 


\section{Ave We a Declining Race?}

serious question. It may be that it is yet a far cry from the present condition of the human race, to that predicted by Mr. Kay Robinson or Dr. Veresaeff, yet it must be acknowledged that we are a very long way from physical perfection, and it may be that there is not so vast a difference in the two conditions as there is in the present state of the human race and that which prevailed among the barbarian inhabitants of Europe prior to the Roman Conquest. This question it would of course be difficult to decide, but by what we may gather from the fragmentary evidence handed down to us, these barbarians must have been exceedingly robust. 


\section{CHAP'TER III.}

\section{Civil and Savage Life Compared.}

" To rear a child is easy, but to teach

Morals and manners is beyond our reach ;

To make the foolish wise, the wicked good,

That science yet was never understood."

-Theognis.

To what extent are we indebted to civilisation for the deterioration of the race?

It is my intention to point out in this chapter, that although we have gained considerably in some directions, by the advance of civilisation, we have lost much in others, and on the whole it is still a question whether life is more tolerable to-day, to the ordinary man in the street, in any city in a civilised country, than it was for the savage before coming into contact with civilisation, or for the ancients?

The question itself I am not in a position to answer, and it is doubtful whether there are many who have had sufficient experience of savage life, with a corresponding experience of the struggle for existence in any of our large towns, to enable them to decide the question satisfactorily.

No doubt we are indebted to the march of progress for much that we enjoy to-day. The meanest man in a civilised community has the advantage of protection and shelter, and although he may sometimes go hungry, he does 


\section{Are We a Declining Race?}

not actually starve. The same man would most likely go under in savage life. Civilisation does away with the law of "the survival of the fittest" in its crudest form, and the unfit are allowed to live.

From the humane standpoint, this is one of the noblest results of civilisation; the protection of the weak from the oppression of the strong.

From a utilitarian standpoint, it might be objected that we not only protect the weak from the oppression of the strong, but we go farther, and allow the unfit free scope in the propagation of their inferior species.

In savage communities, they are generally more careful in this matter, and do not allow any but the fit to marry. This does not apply to the more degraded savage, such as we find in some of the semi-civilised countries, but to the nobler class, such as Mr. Lewis Morgan, in his "Ancient Society," describes as the "grand barbarians." Few are left now, but they might have been found not many years ago, in some of the Kaffir tribes, the Fijians, Iroquois Indians, etc. Of one thing we may be tolerably certain, viz., that physically, we are at the present time very much their inferiors. We find more disease, more pain and suffering to-day, in civilised communities, than they could possibly have had in their lives of action and exposure.

The struggle for existence is perhaps keener with us than with them. This may seem strange when we consider that the savage is often exposed to the danger of dying a violent death, either by 
Civil and Savage Life Compared.

the hand of an enemy, or at the caprice of his chief, or from wild beasts. But when we remember that he generally enjoys perfect health, and should he escape death by violence, lives to old age without suffering any of the inconveniences generally met with in civilised towns, the case bears a different complexion.

With us it is different, for although the more fortunate are born to a state of luxury and indulgence, the proletarian is doomed to perpetual labour, sometimes in most unwholesome surroundings, and always subject to innumerable pains and penalties unknown to the savage.

The idea that pain and suffering is the unavoidable result of civilisation, and that with every refinement of emotion there must be the corresponding degree of physical distress, has been held by many. The late Professor Huxley expressed himself of this opinion. "There is another aspect of the cosmic process, so perfect as a mechanism, so beautiful as a work of art. Where the cosmopoietic energy works through sentient beings, their arises among its other manifestations, that which we call pain and suffering. This baleful product of evolution increases in quantity and intensity with advancing grades of animal organisation, until it attains its highest level in man. Further, the consummation is not reached in man, the mere animal; nor in man the whole or half savage; but only in man the member of an organised polity. And it is a necessary consequence of his attempt to live in this way, that is, under those conditions which are essential to the full develop- 


\section{Ave We a Declining Race?}

ment of his noblest powers."-("Evolution and Ethics.")

In another work he wrote:-

"The amount and severity of the pain have increased with every advance in the scale of evolution. As suffering came into the world not in consequence of a fall, but of a rise in the scale of being, so every rise has brought more suffering."-("Twelve Articles of Scientific Faith..")

If we were quite sure that this theory is correct, there would not be much encouragement for us to go on. Our efforts have been to improve the world, and bring man still higher in the scale of being; but if every rise is to be accompanied by increased suffering, it would be better for us to cease our efforts.

We must all deplore the fact that pain and suffering are on the increase. Perhaps civilisation itself is not entirely to blame, but the mistakes in life that have not yet been rectified by civilisation.

I believe that with a higher conception of life than we have yet held, we shall find that pain and suffering, instead of being unavoidable, may be understood, and can be used as indicators to keep us in a state of perfect health. This seems to be their purpose.

If we examine briefly the marriage systems of the world, we find from the fragmentary histories handed down to us, that each great nation rose to pre-eminence under exemplary sexual restrictions. Also that each declined during periods of licentiousness and abandonment.

Let us take first the ancient Egyptians. Dr. 


\section{Civil and Savage Life Compared.}

Birch, in speaking of the first dynasty, says :"The Egyptian woman appears always as the equal and companion of her father, brethren, and husband. She was never secluded in a harem, but sat at meals with them, had equal rights before the law, served in the priesthood, and even mounted the throne." Rawlinson, writing of the Egyptian of the same period, says :- "With a prudent self-restraint, not often seen among Orientals, he limited himself to a single wife, whom he made the partner of his cares and joys, and treated with respect and affection."-("History of Ancient Egypt.")

Mr. Westermarck writes:- "All the statements we have from the ancient world seem to indicate that polygamy was an exception. . . . In ancient Egypt, as we may infer from the numerous ancient paintings illustrative of domestic life in that country, polygamy was of rare occurrence, and Herodotus expressly affirms that it was customary for the Egyptians to marry only one wife."

What a contrast to the domestic life of three or four thousand years later, after Egypt had survived the Old and Middle Empires, and, after a military age, was fast declining! After the death of Ptolemy Euergetes, "the Egyptian Empire, being governed either by weak monarchs, or wicked monsters, quickly declined, and from that time makes no conspicuous figure in history, except in the depravity of some of its Kings, in which indeed, it may vie with any nation."

Consanguinous marriages were very common; 


\section{Ave We a Declining Race?}

the Ptolomies habitually married their sisters, nieces and cousins.

"Diodorus Siculus informs us that the Egyptians were not restricted to any number of wives, but that every one married as many as he chose, with the exception of the priesthood, who were by law confined to one wife. The Egyptians had concubines, also, most of whom appear to have been foreign women."-(Westermarck; " History of Human Marriage," p. 432.)

Diodorus lived at an age when the glory of Egypt was departing for ever, and he wrote of Egyptian habits as they appeared at the time of Cæsar.'

Thus Egypt rose to opulence and power under exemplary matrimonial laws, and declined in an age of profligacy.- " As Menes in Egypt, as Fohi in China. So Cecrops in Athens, is said to have first brought within restricted limits, the irregular intercourse of the sexes."

Whether these kings were the founders of the institution of matrimony in their own countries, or not, is immaterial ; it is sufficient to know that they ruled peoples who were living under exemplary matrimonial laws. Cecrops, or Kekrops, as his name is sometimes spelt, is said to have instituted laws which forbade polygamy, and the men were not allowed to marry until they were thirty-five years of age. Neither were they allowed to marry within certain degrees of consanguinity.

This limit of age might seem unreasonable to us of the twentieth century, who allow our own children to marry twenty years earlier. 


\section{Civil and Savage Life Compared.}

The statement as to the Athenian age may be disputed; it is a question difficult to verify. I have heard it stated as such, but the only work in which I could find the age mentioned is the "London Encyclopædia." In the article on "Marriage," we read that the Spartans were not permitted to marry until they had arrived at their full strength, that their children might be strong and vigorous and that the Athenian laws are said to have once ordered that men should not marry till thirty-five years of age."

I take this age limit to correspond well with the condition of the people, and there seems to be no other reasonable way to account for the height of glory, opulence, and intelligence to which they attained. It was not by accident that they arrived at that condition; they were bred to it, and when they fell from their most exalted position the cause was obvious, as I shall endeavour to point out later.

Unfortunately, in all accounts of ancient civilisation, the information as to the manners and customs of the people during their rise to greatness is so vague, that we are left to form our own opinions about them. We only know positively of them after they have formed their systems, and are either at the height of their development or are already on the downward track.

The Athenians must have been physically, as well as intellectually, great; as witness Marathon, and their rivalry with the Spartans. It is no doubt owing to the proximity of Sparta to 


\section{Ave We a Declining Race?}

Athens that we have some knowledge of the rise of the Spartans, for they would not be likely to record their own history, as they made a point of discouraging learning.

Mitford says:- "In England the science of breeding horses and dogs of the most generous temper, and highest bodily ability, has been carried to an amazing perfection. Lacedæmon is the only country known in history where attention was ever paid to the breeding of men."

Only think of it! The noblest specimen of creation, and no attention paid to the breeding of him! More than 2,000 years have passed away since the downfall of the Spartan, and during that vast period we do not know of one civilised nation profiting to any extent from the experience of that ancient State.

It is supposed by some that Lycurgus, the traditional legislator of the Spartans, gained his ideas of stirpiculture from Crete, as he had visited that Island during his travels, and their methods of training were similar.

We are told of the Cretans that they were celebrated throughout Greece for the education of their youth. "At the age of seven the boy was permitted to handle the crossbow; from that time he was admitted into the society of the adults, where he continued till the age of seventeen. There, seated on the ground and clothed in a plain coarse dress, he served the old men, and listened in respectful silence to their advice. He was early accustomed to arms and to fatigue, and to endure excessive heat and cold, to clamber and leap among hills and precipices, 


\section{Civil and Savage Life Compared.}

and to bear manfully the blows and wounds he might receive at the gymnastic exercises, or in battle. He was also taught to sing the laws, which were written in verse. . . When he reached the seventeenth year he retired from the society of the adults and became a member of that of the young men. Here his education was still carried on. He exercised himself in hunting, wrestling, and figiting with his companions.

"When the youth had finished their exercises, and attained the legal age, they became members of the class of adults; were permitted to vote in the National Assemblies, and were permitted to stand as candidates for any public office. They were then obliged to marry, but did not take home their wives till they were capable of managing their domestic concerns.

"Under these wise regulations, the Republic rose to glory, opulence and power, and was honoured with the panegyrics of the most celebrated philosophers of Greece. . . . .

"Since the conquest of Crete by the Romans, the Cretans have no longer formed a separate nation, nor made any figure among the states and kingdoms of the world; their noble and ingenuous manners, their arts and sciences, their valour and their virtues, are no more."

The separation of the sexes seems to have been an important point in the training of youth in Greece, as well as the limit of age for marriage.

The Spartans, also, were not allowed to take their wives home until some time after marriage. 


\section{Ave We a Declining Race?}

Mitford tells us that Lycurgus made it criminal for young men to be seen in the company of women, even after they were married.

When first married, the Spartan would have to continue his exercises with the young men by day, and sleep in the common dormitory by night. While these rules were observed both Spartan and Cretan flourished, and their abandonment resulted in the downfall of each.

Physical decline must have been well advanced with the Athenians at the time of Plato, for he seems to have recognised that there was something wanting in their system of intercourse. The old matrimonial system may have been abandoned, for in his "Republic" he thus represents Socrates as conversing on the subject:-

Soc.: "And how can marriages be made beneficial? That is a question I put to you, because I see in your house dogs for hunting, and of the nobler sort of birds not a few. Now I beseech you to tell me, have you ever attended to their pairing and breeding?"

D.: "Exactly."

Soc.: "Why, in the first place, although they are all of a good sort, are not some better than others?".

D. : "True."

Soc.: "And do you breed from them all indifferently, or do you care to breed from the best only?"

D. : "From the best."

Soc.: "And do you take the oldest or the youngest, or only those of ripe age?"

D.: "I choose only those of ripe age." 


\section{Civil and Savage Life Compared.}

Soc.: "And if care were not taken in the breeding, your dogs and birds would greatly deteriorate?"

D. : "Certainly."

Soc.: "And the same of the horses, and of animals in general ?"

D. : "Undoubtedly."

Soc. : "Good heavens! my dear friend, what consummate skill will our rulers need if the same principle holds of the human species?"

D. : "Certainly, the same principle holds good. But why does this involve any particular skill ?"

Soc. : "The best of either sex should be united as often, and the inferior as seldom as possible; and they should rear the offspring of the one sort of union, but not of the other, if the stock is to be maintained."

This is not likely to meet the views of our present day moralists. Yet there is a good deal more humanity in it then there is in our system of indiscriminate reproduction.

Wealth seems to be the most important factor in the institution of matrimony to-day. No matter what the contracting parties may be physically or mentally, money is the great consideration. Lunatics, epileptics, consumptives, drunkards, criminals, deaf and dumb, halt or blind, all are eligible so long as there is a sufficient amount of money forthcoming, and in many cases even where there is none.

But there is no need for us to resort to infanticide to get out of our difficulties. What we do to-day we do in ignorance; we allow 


\section{Ave We a Declining Race?}

the immature and the unfit to propagate their inferior species because we have never taken the trouble to consider the matter; but when we come to consider seriously the claims of our children, and our children's children, we must recognise the injustice of our proceedings, and take steps to discourage improper unions.

The same cause of deterioration is to be traced in the history of all nations.

All authors are agreed that China flourished under the exemplary laws said to have been instituted by Fohi at a very remote age. One of the greatest drawbacks was the recognition of polygamy and concubinage. A very ancient stanza attributed to the great $\mathrm{Yu}$, supposed founder of the Kya, the first of the three most ancient dynasties, indicates that there was a certain amount of philosophy in vogue at the time.

"Within to be addicted to effeminate pleasures,

Without to the sports of the field;

To be fond of wine, of music,

Or of palaces elegantly adorned,

To delight in any of these

Will be doubtless inevitable ruin!"

Anyone who knows the China of to-day, can, with a very little penetration, recognise the cause of their misery, in the physical deterioration brought about by their injudicious connections. Early marriages, coupled with the effects of unnatural vices, have left their impressions.

"Les Chinois qui ont tout inventé avant nous, ne sont pas en reste sur notre race pour la lubricité. Ils y mettent même beaucoup moins de pudeur. Les images masculines, dit $M$. 


\section{Civil and Savage Life Compared.}

Jeannel, se vendent publiquement a Tien-Tsin. Elles sont fabriquées à Canton. Au moyen d'un melange gommorésineux d'une certain souplesse; elles sont coloriées en rose. Des albums vendus publiquement représentent des femmes nues faisant usage de ces instruments qui sont attachés à leurs talons. On en vend aussi comme objets d'art et d'ornement ; celles-ci sont en porcelaine. Des porcelaines peintes représentent des sujets excessivement obscènes; on vend dans les villes du nord de la Chine beaucoup d'albums où la naïveté de l'execution le dispute à l'endécence du sujet. Le prix de ces objets est cependant beaucoup plus élevé que celui des porcelaines et des dessins ordinaires."-(" Jaccoud Dictionnaire de Medicine et de Chirurgie," p. 499, Tom. I4.)

Instances have been known in some provinces of China, where six, and even seven generations, have been represented at the same time in the one family.

Parents view with horror the possibility of their children growing up without getting married; they therefore arrange their betrothals while they are yet infants, and the children consider themselves in duty bound to act accordingly. Dr. Gray says: "Almost all Chinese, robust or infirm, well-formed or deformed, are called upon by their parents to marry so soon as they have attained the age of puberty. Were a grown up son or daughter to die unmarried, the parents would regard it as most deplorable." -(J. H. Gray, "China," vol. i.," p. I86). Surely it is not to be wondered at that a race 


\section{Are We a Declining Race?}

should decline under such a systematic demoralising influence!

"It is now known that some animals are capable of reproduction at a very early age, before they have acquired their perfect characters ; and if this power becomes thoroughly well developed in a species it seems probable that the adult stage of development would sooner or later be lost; and in this case, especially if the larva differed much from the mature form, the character of the species would be greatly changed and degraded."-(Darwin: "Origin of Species.")

I think we may accept this view of Darwin as carrying some weight even with the human species, and when we consider that the smaller and weaker races of mankind are generally those who marry early in life, we may place some confidence in the theory.

The Malays, Veddahs, Andamanese, Siamese, Javanese, etc., all marry=between the ages of eleven and seventeen, and are all of diminutive stature.

On the other hand, we find among savage races, where from various reasons, marriage is delayed until later in life, the men are, as a rule, robust and strong. Among the Zulus, for instance, "Young men who are without cattle have often to wait many years before getting married." -(Westermarck.)

Among the Bechuanas, "the youth is not allowed to take a wife until he has killed a rhinoceros." (Livingstone.) So that they are not likely to marry very early.

Among the wild Indians of British Guiana 


\section{Civil and Savage Life Compared.}

before a man is allowed to choose a wife he must prove that he can do a man's work. In many of the Papuan tribes the bridegroom was compelled to cultivate a certain amount of land for the father of his bride before he could have her. And among the Fijians the unfit were not allowed to marry at all.

These people were all of quite superior physique prior to their contact with us, but the last twenty or thirty years has made a vast difference in the physical condition of many of them. So far the benefits of civilisation have not compensated the savage for the degradation resulting from this introduction to the vicious habits of civilised peoples. Unfortunately, those who first come in contact with savage tribes are seldom the best possible persons to introduce higher ideals of life to them, and there are very few, if any, countries where the natives have really benefited by contact with our civilisation.

The result of European influence on the natives of the Pacific Islands affords us a striking example of the cause of physical decline. One of the most striking characteristics of the natives in former times was the perfect health which seemed their constant possession. Captain Cook tells us of the natives of Otaheitee, discovered in 1767 by Captain Wallis, and visited afterwards by $\mathrm{M}$. Bouganville. "The islanders, who inhabit huts exposed to all the winds, and hardly covering the earth, which serves them for a bed, with a layer of leaves, are remarkably healthy and vigorous, and live to old age without enduring any of its 


\section{Are We a Declining Race?}

infirmities; their senses are acute, and they retain their beautiful teeth to the last."

The first to come under the baneful influence of the foreigner were the first to suffer, and a little more than twenty years later, when Captain Vancouver visited the island, he found that the personal attractions of the women did not correspond with the accounts of former navigators. "According to the natives, they had fallen off in their looks, which they attributed to their indiscriminate commerce with Europeans, and to the loathsome diseases they had received from their visitors."

The Sandwich Islands were discovered by Cook in the year I778. Forty years later the native deterioration was thus commented upon in the "London Encyclopedia" :-

"The face of things since the time of Cook has been completely changed, the cloak of vermil-tinctured feathers once worn by the chieftains has been exchanged for a guise of European fashion, and the plumy sceptre, or kahele, which was wont to precede persons of distinction, is now displaced by some foreign badge of rank and office. . . . . Nor has the outward garb alone undergone a great change since that period, if we may judge of the present generation by comparing them with a few old men who are the survivors of the last; for there has been a great falling off in mental activity and manly fortitude. An observer discovers a certain nobility of disposition indicated by the carriage of the elder race, and a certain frankness of humour of which he cannot discern 


\section{Civil and Savage Life Compared.}

the slightest symptom in their drowsy-headed offspring, who crowd the courts and dwellings of the chiefs. In the room of engaging in those sports and gymnastic exercises, which were once the favourite amusements of his forefathers . . . a native betakes himself to his mat, and solaces his cares by reciting a psalm or portion of Sacred Scripture which the industrious missionary has clothed in the dialect of his willing convert.

"In order to train and bring under subjection the humors of the younger people, an absolute authority over them seems necessary. For where diet, lodging, and climate tend to foster the concupiscible part of our nature, and the restraints of legal enactments, custom and example are scarcely felt, the cordial draught, mingled by Circe for the unwary, becomes far more tasteful, and its draught attended with less remorse than in societies where legislation and the judgment of civil courts provide pains and penalties for transgressors.

"The counterpart of the sirens, fabled in ancient story, who have been deemed by some to exist only in the imagination of poets, may be found at Oahu. . . . He who was so void of understanding as to listen to the pleasing sorcery of their enticements never after felt any longings after the blandishments of home, nor the fond caresses of his wife and children. "And it is no uncommon thing to witness a youth of respectable parentage and hopeful parts, allured, on his first visit to Oahu, into the vortex of sensual delights, and after reeling a few years in dizzy dis- 


\section{Are We a Declining Race?}

sipation, snatched away by a fit of apoplexy, unless he be removed from inevitable ruin by some forceful interposition."

This wantonness, so conspicuous among the women of the Sandwich Islands, and which has resulted in their ruin, was but the result of European influence in the first place. "When visiting the Sandwich Islands with Cook, Vancouver saw little or no appearance of wantonness among the women. But when he visited them some years afterwards, it was very conspicuous, more so than among the worst of the Tahitians, and he ascribes this change in their habits to their intercourse with foreigners."(Westermarck.)

This baneful influence of European vices on native races, is also witnessed among the aborigines of Australia. "The females are, many if not most of them, prostitutes from childhood, and the men not only connive at but offer their wives for the worst of purposes. It is lamentable that the iniquitous example set to the aboriginal inhabitants has, in all countries occupied by the English, been attended by the like evil result-the introduction of European vices and fatal diseases."-("The Aborigines of Victoria," R. Brough Smyth, Vol. II. ; p. 240.)

The aborigines of Tasmania suffered in a similar manner from the same causes, and they have now for some years been totally extinct. The Maoris of New Zealand-a splendid race-have also deteriorated greatly; this also is traceable to the same causes.

If these people retain any recollection of their 


\section{Civil and Savage Life Compared.}

former condition, how they must hate the sight of a white man!

Among almost all South Sea Islanders chastity was considered as a necessary virtue with the young women, and in some cases, even after their contact with foreigners, they were reserved among themselves. Westermarck says: "In Samoa the girls were allowed to cohabit with foreigners but not with their own countrymen, and the chastity of the chief's daughters was the pride of the tribe.

In Fiji great continence prevailed; they had a system peculiarly their own, a description of which I reserve for another chapter.

Although in many of these places the natives wear very scant covering, New Britain was the only place I ever visited where the people of both sexes went entirely nude. This condition, shocking as it may appear to us, seemed quite natural to them; they did not appear to be in any way disconcerted before strangers, and were as modest in their behaviour as any people I know.

A party of five of us went on an expedition to a lake in the interior to shoot casowaries. I saw nothing indecent on the part of the natives the whole time we were on shore. At night we would find one of the most commodious huts prepared for us in the villages that we passed through, and it was remarkable to find that as soon as it began to get dark, the women withdrew from the parts of the villages in which the men slept, to huts of their own.

The separation of the sexes at night appears to 


\section{Ave We a Declining Race?}

be a relic of an old custom of the Papuans, which has gradually been abandoned on coming in contact with European ideas.

"There are numerous savage and barbarous peoples among whom sexual intercourse out of wedlock is of rare occurrence, unchastity on the part of the woman being looked upon as a disgrace and a crime."-(Westermarck.)

Mr. Winwood Reade tells us of the Equatorial savages ol Africa :- "A girl who disgraces her family by wantonness, is banished from her clan, and in case of seduction the man is severely flogged. Theft is also punished by flogging, and adultery by the payment of a large sum, in default of which death or slavery is at the option of the husband." ("Savage Africa.")

The Rev. J. Shorter tells us that the Kaffir laws also were very strict for these crimes: adultery, fine or death; rape, fine or death; murder, fine or death.-("Kaffirs of Natal.")

Winwood Reade wrote of the moral bearing of the people, thus: "For my part I can say that during the whole time which I passed in Africa I never saw so much as one indecent gesture pass between a man and a woman."

Another writer in describing the Kaffirs of South Africa writes:- "A Kaffir woman is chaste and extremely modest."-("Travels in Southern Africa," J. Barrow, Vol. I., 206.)

In treating of these savage races, I have endeavoured to point out three things:-

First, that where it is customary to delay marriage until a more advanced age, we find the people enjoying better health and finer 


\section{Civil and Savage Life Compared.}

physique than where they marry at a very early age.

Second, that in many cases, the savages are really more chaste than the general run of people in civilised countries, and that as a rule they enjoy perfect health.

Third, that they almost invariably deteriorate as soon as they begin to adopt civilised customs (in some cases, whole races die out).

This, in a manner, may explain how pain and suffering have increased, with every advance in the scale of evolution, and later on I hope to show more definitely, that it is decidedly by our own fault that these evils have increased. 


\section{CHAPTER IV.}

\section{A Remarkable Example of Decline.}

"The largest company you could enroll, A single vessel could embark the whole! So few there are: the noble manly minds, Faithful and firm, the men that honour binds; Impregnable to danger and to pain And low seduction in the shape of gain."

-Theognis.

THERE is perhaps nothing in the history of mankind which affords a more striking example of the rapid degeneration of a noble race, than the fall of the Fijian native.

Forty years ago the Fijian might truly have been considered one of the finest specimens of natural manhood in the South Pacific Islands.

To-day, he is in danger of suffering the fate of the Tasmanian, by going right out of existence.

A brief account of his fall, conveying also some idea of his appearance and character in the days of his freedom, may be of advantage to us in the solution of our own all-important problem.

Imagine a powerfully built man, about six feet in height, with intelligent expression of countenance, swarthy complexion, frizzy hair, which, when properly dressed, resembles a huge ball some three to five feet in circumference, having a few crimson leaves inserted by way of decoration; a necklace of whale's teeth, with 


\section{A Remarkable Example of Decline.}

perhaps a large boar's tusk pendant on his chest ; a cloth of native tappa round his waist; with a huge club, artistically carved, in his hand; there you have a fair representation of a Fijian native.

Some idea of his immense strength of arm may be gained by a glimpse at the Fijian clubs to be seen at the British Museum.

In character he might be termed fearless and honourable (he would never attack an enemy without first sending word of his intention), he was truthful, honest in his transactions, chaste in his living; he was also affectionate in his domestic relations, although his method of showing his affection would lead a stranger to suppose that he was just the opposite.

There was another side to his character which must not be overlooked. He was a cannibal, and one of the fiercest; he could also be very cruel to his victims, and club-law was his only method of settling disputes; he was also superstitious; he had a certain veneration for snakes, and he believed in some sort of a future existence.

One of his worst superstitions was that when a chief died it was necessary that his wives should accompany him to the unknown world, therefore the wives were strangled and buried with him. This inhuman practice, or inhuman as it must appear to us, was one of the Fijian ways of showing affection; the wives, sincerely believing that they would live with their husbands in another state if they were buried with them, deemed their relatives unkind if this terrible duty was neglected, and in some cases they have 


\section{Ave We a Declining Race?}

been known to commit suicide deliberately rather than be left behind. Another peculiar method of showing affection was that when parents became old and decrepit, with no further prospects of enjoyment in life, their children, still exhibiting the deepest tokens of affection, would bury them alive. Instead of wearing crape as a token of mourning, they would take a piece of shell and saw off one of their own finger-joints.

We now come to the most important part of their regime-the matrimonial. They had a system of polygamy, by which the chiefs had three or four wives. In Fiji a plurality of wives was looked upon as so much property, rather than as the means of gratifying the passions, therefore it was the best system which could have prevailed under all the circumstances. The chiefs were naturally the best men, and the race was propagated from the best stock, while the majority of the less perfect remained chaste. The term chaste may be applied here, I think, in its fullest sense. Take the following from "Vita : an Account of a Government Mission to the Fijian Islands," by Bardolph Seemann, Ph.D., F.L.S., F.R.G.S., as an example of village life :-

"The men sleep at the Bure-ni-sa, or stranger's house, those of about the same age sleeping together; whilst the boys, until they have been admitted publicly into the society of the adults, have a sleeping bure to themselves. It is quite against Fijian ideas of delicacy that a man ever remains under the same roof with his wife or wives at night. [Italics mine.-W. H.] In the morning he goes home, and if not employed in 


\section{A Remarkable Example of Decline.}

the field remains with his family the better part of the day, absenting himself as the evening approaches."

"Rendezvous between husband and wife .... are arranged in the depths of the forest, unknown to any but the two. After child-birth husband and wife keep apart for three, and even four years, so that no other baby may interfere with the time considered necessary for suckling children in order to make them healthy and strong." This in a great measure explains the existence of polygamy. The relations of a woman take it as a public insult if any child should be born before the customary three or four years have elapsed, and they consider themselves in duty bound to avenge it in an equally public manner."

One could scarcely conceive of a more exemplary little community, from its own moral standpoint. The sexual idea was scarcely known among the ordinary people. The rank and file of the village folk knew that the matrimonial state was beyond their scope, and they did not trouble their heads about it; another reason for their not troubling about it was that adultery was a capital crime. Dr. Seemann tells us that Keraduadua clubbed one of his own nephews for being unduly intimate with one of his wives. Thakombau is said to have cut off the nose of one of his sisters for this offence.

* Similar customs are described by Winwood Reade in his book, "Equatorial Africa." It is also to be noted that in Ashanteeland the mother keeps apart from the husband until the child is weaned.-W. $\mathrm{H}$. 


\section{Are We a Declining Race?}

These people were very intelligent, as might be inferred from their mode of life. Not only were they satisfied with their own system, but they could see the weakness of ours. According to Dr. Seemann, one of them asked a white man how many brothers and sisters he had; the white man frankly answered him, "ten." "But that could not be," was the rejoinder, "one mother could scarcely have so many children." When old that these children were born at annual intervals, and that such occurrences were common in Europe, he was very much shocked, and thought it explained sufficiently why so many white men were " mere shrimps."

Here is a lesson in philosophy from the Cannibal Islands. It seems to me that the tables should have been turned, and instead of sending missionaries out there to convert natives to our ideas, we should have sent men for the purpose of learning something from them, or, at the most, of making a friendly exchange of ideas.

The Fijians were very much imposed upon at that time, by the white settlers, and there were several disputes as to ownership of land, etc. On one occasion the Americans had been keeping up the $4^{\text {th }}$ of July, "Yankee Day," as it is termed, the celebration being held at the house of the American Consul. During the night a fire broke out in some sheds that they used for drying "bêche de mer," and they accused the natives of incendiarism. They held a court of inquiry and fined the king a certain amount of money, getting him to put his mark to a certain document. Seeing that the Fijians possessed no money, this 


\section{A Remarkable Example of Decline.}

was a bit of a farce. However, the fine, whatever the amount might have been, remained unpaid until, in the course of a few years, with the interest it mounted to nine thousand pounds. Then certain speculators formed a syndicate which was to relieve the natives of this embarassment; this precious scheme was termed the "Polynesian Land Syndicate," or some such title, and its members agreed to pay the Americans out; "to give Cakobau $£ 200$ per annum, to each of his chiefs $£$, and to assist Cakobau in upholding and defending his kingdom. In return they were to have 160,000 acres of land of their own choice, the sole right of levying duties on imports and exports, with wharfage and harbour dues, the sole right of banking and issuing of bank-notes, a pre-emptive right over all land which Cakobau might hereafter wish to sell, and full power to make laws for the good Government and welfare of the natives and settlers at any time."

By another clause, Cakobau was " to clear and plant with sea island cotton for the said company, without delay or charge, acres of the land, at such places and times, as the company should direct."

Cakobau's mark was actually put to this document, when another factor appeared in the shape of the British Government. The claims of the Polynesian Company were ignored altogether. The Americans were paid out with 45,000 dollars, and the British Government was to receive 200,000 acres of land of its own choosing. 


\section{Are We a Declining Race?}

Thus were the natives involved in heavy obligations as a result of a calamity with which they, perhaps, had nothing to do. Such transactions generally lead to a lot of bloodshed, and the native always goes to the wall. There were several disturbances over the land question. In I 868 H.M.S. Challenger sent a punitive force up the Rewa, consisting of four boats and eighty.six men, with two Armstrongs. Again, in 1873, there was a disturbance, with a slaughter of about 400 .

After many lives had been lost, Cakobau was persuaded to petition the British Government to establish a Protectorate over them, with the result that the Fijian Islands were annexed by us in 1874, under the direction of Sir Hercules Robinson, Governor of New South Wales at that time.

Cakobau's speech will give some idea as to their condition at the time :-

"Any chief who refuses to cede cannot have much wisdom. If matters remain as they are Fiji will become like a piece of driftwood on the sea, to be picked up by the first passer by. The whites who have come to Fiji are a bad lot. They are mere stalkers on the beach. The wars here have been far more the result of interference of intruders than the fault of the inhabitants. Of one thing I am assured, that if we do not cede Fiji, the white stalkers on the beach, the cormorants, will open their maws and swallow us."

This does not redound much to the credit of "the white stalkers on the beach"; still it seems 


\section{A Remarkable Example of Decline.}

that the ultimate fate of the Kanaka in all those parts is to be swallowed up.

As soon as the freedom of the natives was signed away, they were given to understand by the missionaries that they were now British subjects, and that polygamy was illegal.

The first thing they did, therefore, was to annul all the old polygamous marriages, and distribute the women amongst all sorts and conditions of men.

No doubt the missionaries thought they were doing quite right in this matter, but I ask, was it not a monstrous thing that they should have been allowed a free hand in matters of such vital importance as the breaking up of homes, and systems, without any other apparent means of discrimination than their religious zeal ?

The Fijians had a system of domestic regulation that was truly marvellous, considering the state of savagery in which we found them. One might imagine that they had had some of the knowledge of ancient Greece, so similar were their customs of separating the sexes, public sleeping bures, and propagating the race from the best stock, etc. Plato himself could scarcely have improved on the system. Would that there had been a Plato, or a Lycurgus, in the place of those missionaries!

Their action, in the breaking up of those homes, was irremediable. When the mothers were dispersed, those young virgins, who had been so jealously guarded by them, were dispersed also, and there were not wanting those (not only natives), ready to take advantage of 


\section{Are We a Declining Race?}

them, and their liberty was too quickly turned into license.

Licentious ideas had already been introduced among some of the male population, and it did not require much persuasion to convert the whole group of islands in to a huge agapemone.

This universal matrimony was a new idea, and the lower orders took to it most readily. Many of those who were not, physically, so well favoured as others, and who had never entertained any ideas of marrying, suddenly found themselves confronted with the opportunity of taking a wife. Naturally, they lost no time in seizing it ; it was a case of "Barkis is willin"," without any time lost on courtships, and they kept the missionaries quite busy for a time with the interesting ceremony.

A lady in the Governor's household, wrote from Fiji to a friend:- "To-day being Sunday there has been much church going.

After morning service there were no less than thirteen weddings. . . . The superfluous wives are in much demand by men who hitherto have failed to secure domestic bliss." In another letter she wrote:- "So it happened that on reaching this place, Nirukuruku, three days ago, we found no less than forty couples, belonging to this and the neighbouring villages, all waiting to be married on the arrival of the missionary." From another place, she wrote:"There is a perfect crowd of interesting young couples, just coming in to be married, so I must watch the proceedings."

The ceremony itself, no doubt, seemed to be 


\section{A Remarkable Example of Decline.}

innocent enough, and very interesting, both to the missionaries, and to the onlookers, who were in sympathy with them; yet there were others who viewed these proceedings with far different feelings than those of approval. Pessimists, some perhaps will say, yet subsequent events showed that there was reason in their pessimism.

I mentioned before that this universal matrimony was a new idea, and, like all new ideas, it was carried to an extreme. With what results? Within twelve months of the annexation, the Fijians were overtaken by a great calmity; an epidemic of measles ravaged the whole group of islands, carrying off some forty thousand natives.

This was all the more significant, as such a disease as measles was quite new to them.

Many of the more superstitious looked upon this as a judgment on them for changing their mode of life, and giving up their lands, so they fled to the mountains, and some time and trouble were involved before they could be prevailed upon to return.

Following the measles, they were attacked with catarrh; then with whooping cough among the children.

These seemed to be but the commencement of their troubles, and when the census of I88I was taken, it was found that the native population had decreased in numbers to the extent of about fifty thousand. The estimated population at the time of the annexation in 1874 was 150,000 ; in I 897 the native population was 99,773 .

As the Europeans prospered in wealth, so the Fijians deteriorated in physique, until at length, 


\section{Are We a Declining Race?}

in I893, if was found necessary to appoint a Government Commission to inquire into the cause of the decrease of the native population.

What I have but hinted at here was fully borne out by the investigation. The methods adopted by the Commissioners was the issuing of a circular note to all the principal Europeans and the native chiefs, soliciting their views on the subject.

Some of the answers sent in were very suggestive of its being an entirely moral problem. As might be expected, the answers and opinions received varied a good deal; some were very elaborate and wide of the mark, others more simple and to the point.

Yaqona (or Kava) drinking and tobacco smoking seemed to occupy the most attention. Yaqona used to be considered quite a harmless beverage, its chief effect being to induce sleep, while the use of tobacco, although not commendable, would scarcely lead to such disastrous results. A few of the letters however, throw some light on the subject.

On page 8 of the Commissioner's Official Report, we read:-

"Four writers indicate as the primary cause the circumstances arising from the abolition of polygamy, on the introduction of Christianity. Others cite that event, but only as a minor cause. One ascribes it to "the more frequent bearing of children by the mothers!' Another, 'That the mother is not so well cared for as under the old regime, when she was allowed four years to nurse her child, and was relieved during 


\section{A Remarkable Example of Decline.}

that period of all domestic duties beyond nursing the baby, a system which placed the mother in the best possible position to rear her child. Monogamy prevents this, and the injurious nature of the change is emphasised by the fact that the Fijian has no possible substitute for mother's milk.'

"That the women have now to rely, when in travail, on the good offices of some old woman, instead of being, as formerly, well looked after by the other female members of the household, who took as much interest in the unborn babe as the mother herself.

" That in polygamous times the best females of the race bore children to the best males, and the progeny was consequently robust; but that many of such women are now the wives of an inferior class of men, who, under a polygamous regime, would probably never have obtained wives, and would thus have been prevented from procreating their inferior species.

"That in polygamous times the wives, from a spirit of emulation, tried to rear their children, and succeeded in doing so, and that it was not not at all uncommon for a man to rear ten or a dozen children.

"That the people who practised polygamy, the chiefs, were better able to maintain their wives in food and comforts than the men of lower ranks, who form the majority of monogamous husbands.

"That on the abolition of polygamy, the young girls were set free from the repression formerly exercised over them, and converted 


\section{Ave We a Declining Race?}

their freedom into license, a change which has borne fruit, in the present age, in the form of sexual irregularities and dislike to marriage, and that when they enter that state their duties as workers prevent them performing those of mothers."

Here are a few official opinions cited in the Report :-

"Monogamy has increased the work of the women. They did not, perhaps, like all things connected with a state of polygamy; but on the whole, I believe, they like the incessant work entailed by monogamic life still less.

"The law and that which Mr. Blythe, a little oddly, perhaps, describes as 'Missionary Monogamy,' has altered this state of things.

"The wife has now to work at all times for her husband. She has, so she says, no rest, and that which she hates still more than work, is the advances of her spouse, whether while enceinte or nursing.

"The man abhors being tied to a woman. . . . To both parties the idea is as repugnant as can possibly be conceived. If the man's advances are, however, persistent, the woman neglects her child, and says the husband is killing it."

In another part of the Report there is mention made of a vice, which although common enough in European and Oriental countries, was, I believe, unknown to these people formerly: "One writer states that the use of tobacco (coupled with the practice of self-abuse) by men, women, boys, and girls, is the most potent factor affecting the decrease of population." 


\section{A Remarkable Example of Decline.}

Although there is only one mention of this vice (self-abuse) made in the Report, I think it very likely to have been in practice among them at the time, for wherever we find a loose morality, this vice is almost sure to be prevalent. This would also account to a very large extent for the rapid decline of physique.

"The principal charge against tobacco is that pregnant women and nursing mothers smoke immoderately to the detriment of the infant, and, in many cases, cause the death of the children."

These people were addicted to the use of tobacco long before they became British subjects, and at that time it would have been difficult to find healthier babies than theirs, so that, although smoking is a bad habit, and one likely to cause a slight degeneration, it is hardly significant enough to offer as a solution of the problem.

Some of the missionaries themselves seemed to recognise that a mistake had been made in forcing our ideas of morality on them, and acknowledged their belief that immorality was the principal factor in the decline of the race. The following is a remarkable admission made by one of them-Rev. W. Allen, Wesleyan Missionary-which reflects credit on the integrity of the writer:-

"It is to be feared that a great deal of immorality, at the present time, exists with married women as well as single. . . . I am inclined to think that since the introduction of Christianity and settled government, illicit intercourse among the sexes has very greatly in- 


\section{Are We a Declining Race?}

creased. Being released from the barbarous club-law, and with no healthy public opinion among themselves on those matters to deter them, many have abused their liberty, using it as an occasion for lasciviousness."

He recommends that a pamphlet should be written in the native language and be distributed among them.

This is most assuredly a practical admission of the failure of missionary enterprise, after twenty years of unopposed influence, and the apparent conversion of the whole race to Christianity. This recommendation also shows the weakness of our moral code ; verbal demonstration in such matters is tabooed, and recourse must be had to an obscure pamphlet !

What a difference between this picture and that of Dr. Seemann! "It is quite against Fijian ideas of delicacy that a man ever remains under the same roof with his wife, or wives, at night." The Fijian as a savage was in many respects much superior to the Fijian as a British subject.

Another missionary (Rev. H. Warrall, Wesleyan, Rewa), writes:- "As a missionary in charge of the largest circuit in Fiji, I am brought in contact with more than 2,800 natives, so, in considering the environments of these, I am probably considering what fairly applies to the whole race. I say, without doubt, that the most alarming factor in the sum total of the problem before us is the rapid increase of immorality. It is also impossible for me not to recognise the very alarming fact that a large percentage of this evil is to be laid to the charge of the high 


\section{A Remarkable Example of Decline.}

chiefs, some of whom hold responsible positions in the Government. . . . Immorality, so the history of nations declares, has always militated against the best interests of the human race. Since the abolition of club-law, immorality has increased alarmingly. While I do not for a moment wish to imply that I advocate the reestablishment of this summary form of punishment, I do sincerely and respectfully advocate a more general application of the law."

It is a great mistake to think that immorality can be put down by any application of the law. If moral suasion fails, punishment is worse than useless. The Rev. W. Allen's suggestion of a pamphlet is a very practical remedy, which appeals to the reason, by pointing out to the natives how they suffer by giving way to their passions: they might be weaned from their vices, and be taught self-respect ; whereas punishment is degrading.

Another writer (Rev. W. Slade, Wesleyan Missionary, Gaviau) :- "The Fijian mother is undoubtedly very careless of her offspring. The reason is to be found in her unstable character. The cares of maternity appear to become somewhat irksome to her. For long periods she leaves her offspring in charge of children who are themselves mere infants, and at such times the helpless child is wholly without nourishment. . . The chances of the Fijian mother bearing healthy children are lessened by her loose morality. I have been shocked to find at what an early age "native 'girls surrender their virtue." 


\section{Are We a Declining Race?}

It would be almost impossible to imagine a greater contrast between the loose morality revealed by these letters, and the former condition of these people. The devotion of the women to their children, both before and after birth, was almost phenomenal. In polygamous times the woman separated from her husband as soon as she became enceinte, and the other women of the household used to guard the interests of the unborn child as jealously as if it were their own. It is a recorded fact that on one occasion when a young chief was killed, one of his two wives, who were to be buried with him, was found to be with child, upon which another woman, in order to save the child, volunteered to take the young wife's place, and was strangled in her stead.

Such devotion to the unborn babe is perhaps unknown in any other history, and yet we now find these people sunk to the low condition depicted in the foregoing extracts.

The Rev. A. J. Small was of opinion that the decrease of native population "would have been apparent to-day, even if they had never seen a European." How could the reverend gentleman make such a statement? Had he taken the trouble to look up the folk-lore of the people, whose spiritual condition he had undertaken to improve, he would have found that their first important physiological trouble was an epidemic of dysentery, which appeared with their first acquaintance with the white man. Prior to that, disease was, comparatively speaking, unknown. 


\section{A Remarkable Example of Decline.}

The Rev. F. Langham, Chairman, Wesleyan Mission, did not ascribe their decline to immorality, but thought that "frequent abortions might have some influence in the matter."

Mr. Langham being one of the oldest missionaries in that part, one might have expected some enlightenment from him. Still, on the whole, we have gained some wonderful admissions from the missionaries, all tending to show the real cause of the Fijian decline.

It seems hardly credible, that such a fearless and warlike race, could have been cowed down to the extent that they were, and in such a few years. Had the main object of the Europeans been to bring them into utter subjection, they could not have adopted a more effectual plan. Yet the people who were the cause of this subjection were as much bewildered as its victims.

Lord Stanmore, formerly Sir A. H. Gordon, first Governor of Fiji, was invited to attend the Missionary Conference at St. James's Hall on May 3Ist, I894, to give an account of the effect of missionary enterprise in that part of the world.

To judge from the report published by the Daily Chronicle on the following day, those who expected to hear something laudatory of missionary influence, must have experienced a shock at the tone of Lord Stanmore's address.

In describing village life, he said :-

"In the centre of the village is the cricket field, a desolate expanse of dry earth, on one side of which is the church, a wooden, barn-like 


\section{Ave We a Declining Race?}

building. If entered, it will be found filled with crazy benches; beyond them, rises a huge octagonal pulpit, in which, if the day be Sunday, we shall find the native minister arrayed in a greenish black swallow-tailed coat, a neckcloth once white, and a pair of spectacles, which he probably does not need, preaching to a congregation, the male portion of which is dressed in much the same manner as himself, while the women are dressed in old battered hats and bonnets, and shapeless gowns like bathing dresses, or it may be crinolines of an early type. Chiefs of influence and women of high birth, who in their native dress would look, and do look, the ladies and gentlemen that they are, by their Sunday finery, given the appearance of attendants on Jack-in-the-Green. Hard by is the school, where, owing to the proscription of native clothing, the children appear in tattered rags, under the tuition of a master, whose garments resemble those of an Irish scarecrow, and they are probably repeating a list of English counties, or some similar information equally useful to a Polynesian Islander. . . . The whole life of these village folk is one piece of unreal acting. . . . Their faces have, for the most part, an expression of discontent, they move about silently and joylesśly; rebels at heart to the restrictive coils on them.

They have good ground for their dissatisfaction. At the time when I visited the village I have especially in my eye, it was punishable by fine and imprisonment to wear native clothing; punishable by fine and imprisonment to make 


\section{A Remarkable Example of Decline.}

native cloth; punishable by fine and imprisonment to smoke tobacco; punishable by fine and imprisonment to make the native beverage, Kava; punishable by fine and imprisonment to wear long hair, or a garland of flowers ; punishable by fine and imprisonment to wrestle, or play ball ; punishable by fine and imprisonment to build a native-fashioned house; punishable not to wear shirt and trousers, and in certain localities, coat and shoes also ; and in addition to laws enforcing a strictly puritanical observance of the Sabbath, it was punishable by fine and imprisonment to bathe on Sundays. In some other places bathing on Sundays was punishable by flogging, and to my knowledge, women have been flogged for no other offence by order of a native teacher, whose action was by no means so decidedly disapproved of by his white superior as it should have been. Men in such circumstances are ripe for revolt, and sometimes the revolt comes."

What a misery such a life must have been to those people, who had formerly enjoyed absolute freedom! Can it be wondered at, under the circumstances, that they gave way to immorality, if only to break the monotony of such an existence?

However, the whole weight of the responsibility rests with us. We, however reluctant to admit it, have forced our inferior system (inferior from a physiological aspect) on them, and it is our duty to try and rectify the evil. To revert to their old system would be impossible, unless we give them back their lands; even then the 


\section{Ave We a Declining Race?}

prevalence of erotomania would prevent the return to their former innocent life. By innocent life, I do not mean cannibalism and club-law, but innocence from a moral aspect.

My aim in dwelling on the troubles of these people is to point an object lesson from which we may derive some inkling as to the cause of our own.

We are so much in the habit of assuming that savage races are devoid of all reason that we are surprised to find them in possession of laws of any description; much more so to find them with regulations superior to our own, as some of them certainly are. Take, for instance, the cessation of intercourse during the periods of gestation and nursing. A most exemplary rule. A rule which would make a vast difference in our infant mortality if adopted by us.

Similar rules to this were in force in different parts of Africa, according to Mr. Winwood Reade and others. "The child is introduced into the world without medical aid, and is cordially welcomed. . . . The mother is treated with great respect, and is exempt from all labour while she continues to suckle her child, which she continues to do while her milk lasts. . . During this time, and almost from the moment that impregnation becomes apparent, the mother no longer cohabits with her husband. Otherwise, say the natives, the child would be born sickly or crippled (in which case it would be killed), and the milk would be spoiled."

I know of no civilised place where the com. 


\section{A Remarkable Example of Decline.}

mon practice is equal to this. It seems to me the very acme of philosophy. And yet we go to these people with our assumption of superiority, and instead of being wise enough to inquire into their habits of life, we force our creeds, superstitions, and vices on them whether they wish it or not. 


\section{CHAPTER V.}

\section{The Cause.}

"Loose Thoughts like subterranean Fires, Burn inward, smothering, with unchaste Desires; But getting vent, to Rage and Fury turn, Burst in volcanos, and like Etna burn,

The Heat increases as the Flames aspire, And turns the solid Hills to liquid Fire.

So sensual Flames, when raging in the Soul, First vitiate all the Parts, then fire the Whole;

Burn up the Bright, the Beauteous, the Sublime, And turn our lawful Pleasures into Crime."

-Daniel Defoe.

I HAVE endeavoured in the preceding chapters to point out the connection between physical decline, and profligacy and licentiousness; also that it may be traced, in a milder form, to propagation from the undeveloped species.

I am well aware that there is nothing new in all this. Unfortunately, many efforts are being made to divert the public attention away from the real facts of the case.

Many expert writers are now employed on the subject of the physical deterioration of the masses. No doubt they are doing a great amount of good socially, but their many volumes on the improper feeding of children, insanitary slum dwellings, insanitary workshops, the vitiated and smoke-laden atmosphere of large towns, etc., do not grapple the all-important problem.

The man who deals with the question effectu- 
The Cause.

ally, must probe the painful business to the very core. This cannot be done without hurting the feelings of many who will resent the operation, and, perhaps, abuse those who inflict the pain for the public welfare. "The diseases of society can, no more than corporeal maladies, be prevented or cured without being spoken about in plain language." It was true when these words were penned by John Stuart Mill, and it is as true to-day.

My attention was first called to the subject of physical degeneracy some thirty years ago, by the disastrous results of a certain vice (masturbation) practised by boys at an establishment where I resided for some nine or ten months. There were about eight hundred boys in residence there at the time; they ate, drank, and slept together, so it is no wonder that the vice, once introduced, soon spread throughout the whole community. I became aware of the prevalence of this vice among the boys before I had been there many days, and also of the fact that, as a result, their constitutions were being ruined. The boys became pale and emaciated, and were soon subject to all sorts of petty ailments, and, later on, some of them to absolute disease. Remonstrance seemed useless at that stage, for they always denied indulging in the habit, so that it went on unchecked, except by an occasional caution from one or two who understood the nature of the evil.

Some nine or ten years later I was at a similar establishment, and was again shocked to find every indication of the existence of this same vice. 


\section{Are We a Declining Race?}

Since that period I have constantly come into contact with evidence of its existence in various parts of the world. Latterly, its demoralising influence may be observed in all classes of the community. There is scarcely a school, according to medical evidence, where it is not indulged in by the children of both sexes, and its influence is being felt throughout the civilised world to-day as the cause of deterioration.

There is ample reason for supposing that the influence of this vice has affected various parts of Europe, at different periods, like a blight, for the last two thousand years and more. I have spent many hours, and searched some thousands of volumes in tracing its history, and I therefore venture to hope that the result of my studies may be of some use.

The reluctance with which most English authors approach subjects connected with sexual matters and all things connected with the organs of generation, has rendered it extremely difficult to deal with such a subtle vice as masturbation.

However meagre the allusions made to it in history, it can scarcely be doubted that the vice has played a very important part in the downfall of nations. Without attempting to trace it among the bewildering religious ceremonies of the Orient, from which quarter it was probably introduced into Europe, it will be sufficient to note the first records of its existence there. Although we find it stated that the habit was prevalent among both the Egyptians and Greeks, it is highly improbable that it was so, to any extent, until they had attained the very height 


\section{The Cause.}

of their culture, and it is then that we first find any mention of its prevalence. It is significant that both nations began to decline very rapidly, so soon as they came in contact with the Persians, whose depraved physical condition was almost phenomenal at the time.

The earliest mention of the habit in Europe, so far as I am aware, is in connection with Sappho, the celebrated Greek poetess, who is said to have founded at Lesbos a school of young women who made a boast of their indulgence in it. "Chez les Grècs, Sapho, qui était possédée de cette passion, fit école. Elle s'entourait de jeunes Lesbiannes, qui professaient le mépris pour les hommes, et qui se vantèrent d'ériger sans eux et à elles seules, un nouveau culte à Vénus. Elles furent surnommées Tribades."Jaccoud Dictionnaire de Médecin et de Chirurgée. We also find a similar statement in the Dictionnaire Encyclopédique des Sciences Medicales :- "Sapho est accusée d'avoir la première introduit et repandu la pratique de l'onanisme lacoul parmi les jeunes filles de Lesbos, d'ou le nom de lesbianisme."

Emanating from such a source, one can imagine how rapidly such a practice would be communicated from one to another throughout the State, and the amount of harm which would result from it. That it was communicated is evident, for we find frequent mention of its prevalence with the other sex at a later period.

"Dans l'ancienne Grèce, certaines écoles philosophiques poussaient trés-loin le mépris de la femme qu' Aristotle considérait comme une 


\section{Ave We a Declining Race?}

irrégularité de-la nature; elles preféraient l'onanisme aux rapports sexuels. On était en outre, poussé aux manœuvres onanistiques par les théories médicales regnantes. D'après ces théories, que Galen nous a conservées, le sperme devait être considéré comme une chose nuisible, dont il y avait necessité de débarrasser le corps. Et Diogène qui affectait de ne faire aucun cas des faveurs que lui prodiguaient les plus belles femmes de son temps, se satisfaisait honteusement dans la rue au milieu de la foule. Beaucoup d'honnêtes gens, contemporains du cinique, imitaient sa conduite."- " Encyclopédique".

Hippocrates denounced the habit as a vice which was the cause of many diseases, among others consumption. Profligacy of any description, in fact, was recognised by him as productive of disease.

M. Mauriac, in an instructive article on "Onanisme," in the "Jaccoud Dictionnaire," tells us :

"L'abus des plaisirs de l'amour a toujours été regardé, par les médecins et par les moralistes comme une cause puissante de déterioration pour l'organisme, et de dechéance pour les facultés intellectuelles et morales. Trois cents avant notre ère, Hippocrate traçait le tableau des désordres qu'il produit et en désignait l'ensemble sous le nom de consomption dorsale.

"Grave et difficile problème. Depuis plus de vingt siècles, il a été formulé par le père de la médecine, et aujourd'hui est-il résolu? C'est ceque nous discouverons plus loin.

"Depuis Hippocrate, des médecins illustres 


\section{The Cause.}

dans l'antiquité et les temps modernes, ont attaqué de front ou traité incidemment la grosse question d'hygiène individuelle et sociale, qu' impliquent l'exercice, et surtout l'abus et la perversion des fonctions genitales. En géneral, ils n'ont fait que paraphraser le passage qu'on trouve dans le traité, De morbis, sans avoir paru remarquer et comprendre la conception étiologique du tabes genitalis que je signalais plus haut. Aussi me semble-t-il inutile de donner des citations textuelles. Qu'il me suffise de nommer les auteurs les plus célébres: Celse, Aretée, Galien, Santorini, Hoffman, Boerhaave, Senoc, Van Swieten, Levis, Storck, etc."

Hippocrates was evidently the principal authority of his day, and for many succeeding generations. It is not altogether surprising that his attention should have been drawn to the effects of "L'abus des plaisirs de l'amour," considering that he lived at a time when the Greeks, by their profligate habits, were preparing the way for their ultimate degradation, "a period in which sensuality was almost unbridled."

Although we look upon the period just prior to, and the commencement of, the present era as being the most immoral, some authors seem to think that the vice was not so prevalent then as in more modern times. It would, of course, be difficult to guage the standard of physique at so remote a period in order to make comparison with the present day. "Cependant en reflechissant sur les moeurs austeres, le genre de vie, et la nourriture des anciens, en comparant leur force et leur vigeur à la nôtre, nous avons tien de 


\section{Ave We a Declining Race?}

croire que l'onanisme était beaucoup moins commun chez eux qu'il ne l'est chez les modernes, dont le genre nerveux est plus irritable par l'effet d'une infinité des causes que les anciens ignoraient."-(Aloyce Schwartz, "Dissertation sur les Dangers de l'Onanisme.")

This may be perfectly true, for when we consider the enormous incentive to vice during the intervening centuries, caused by an ever increasing population; the demoralising effects of people being pent up, sometimes for many months, in besieged cities; the existence of slum areas in all large towns; the increasing consumption of alcohol, and many other influences in connection with the growth of civilisation, we cannot wonder that secret vice should have gained ground among the people.

The ancients were also publicly cautioned against the evil effects of sexual vices, and we read of such men as Hippocrates, Aristotle, Democritus, Actius, Celsus, Sanctorius, and even the much-traduced Epicurus, who have given their testimony against the dissipation of the "vital fluid."

Tissot says :- "Epicurus, that respectable man who knew better than anyone that man could be happy only by pleasure, but who, at the same time, limited this pleasure [Ordinary Sexual Congress] by such a rule that a Christian hero would not disprove of. Epicurus looked upon the seed as part of the soul and body, and upon this opinion he founded his precepts, which enjoined its preservation."

Galen is the last to discuss these matters 


\section{The Cause.}

freely, and for many centuries the public mind appears to have been too much engrossed with religious affairs to leave room for such subjects; therefore the world was left in darkness, so far as written testimony goes, until the eighteenth or possibly seventeenth century, when the ravages made by sexual vices had become so apparent that a few of the bolder spirits of the medical profession came to the front to warn us of the evil of these vices.

These generally met with rebuke from the more orthodox, who preferred to go on practising the healing art without concerning themselves much about causes.

Frederick Hoffman, an eminent physician of Hall, near Magdeburg, and the celebrated Herman Boerhaave, of Leyden, were among the first to write on this subject at the commencement of the eighteenth century. They were followed shortly after by Dr. Tissot, author of the famous "Traité de l' Onanisme," which traced many diseases to that evil. A twentieth century writer, styling himself John Allen Godfrey, says that Tissot erected a "colossal bogey" when he wrote his "Traité del'Onanisme."

John Allen Godfrey wrote in advocacy of the very vices denounced by Tissot and others, but I believe his book, entitled "The Science of Sex," has been suppressed. It was a work calculated to do much harm in the hands of single people and widows, to whom he recommends occasional masturbation as a "nervous sedative " and "a clarifier of the mind." Nothing could be wider of the truth, as I shall endeavour 


\section{Ave We a Declining Race?}

to show later on, by reference to other medical works.

Numerous works were produced by Continental writers during the eighteenth and nineteenth centuries, dealing with this question, and many and varied were the opinions called forth.

It would appear that England had kept itself comparatively free from the grosser evil until well into the nineteenth century, for we find very little mention of it until that time. Daniel Defoe, although severely criticising matrimonial indiscrimination in his satire, "Conjugal Lewdness," made no mention of solitary vice. Had such been prevalent in England at the time of his writing (1727), it would hardly have escaped his attention, and would have called forth more scathing denunciation even than matrimonial wantonness. This apparent immunity might be accounted for by the comparative isolation brought about by the sea barrier. At any rate, the physical decline was not so apparent among the English people until after the Peninsular War, when our troops probably became contaminated with the vice, as they certainly were with syphilitic diseases. That masturbation was prevalent among Continental troops is evident by the statement of M. Christian: "Armées en campagne, matelots isol s sur les navires, tous payent leur tribut à cette loi fatale." Seamen, also, may have helped to introduce it in Great Britain.

Evidence of a rapid deterioration during the last century is traceable in the reduction of the standard for recruits in the army. In I845 the standard of height in the British army was $5 \mathrm{ft}$. 


\section{The Cause.}

6 in. In 1872 it was reduced to $5 \mathrm{ft} .5 \mathrm{in}$., in 1883 to $5 \mathrm{ft}$. $3 \mathrm{in}$., in 1897 to $5 \mathrm{ft} .2 \mathrm{in}$., and in Igor "specials" were actually enlisted as low as $5 \mathrm{ft}$.

In 1845 the proportion of soldiers under $5 \mathrm{ft}$. 6 in. was about one-tenth; in 1900 it was 565 per $\mathrm{I}, \mathrm{O00}$, or more than one half.

In I901, I1,896 men were examined, and 8,820 , or nearly three-fourths, were rejected.

These figures were published in the Lancet of May, 1902.

There is nothing to show that this rapid decline has ceased, so that we are truly in a serious plight.

I have already mentioned the name of Sir W. C. Ellis in connection with the rapid increase of lunacy. In his "Treatise on Insanity" (1838) he devoted several notes to this habit as a caution to the medical profession, as thus:"Masturbation —_ is a fertile source of insanity. I have no hesitation in saying that in a very large number of cases, in all public asylums, the disease may be attributed to that cause. The general debility which is caused by this disgusting habit, is more severely felt in the brain and nervous system in some constitutions than in others, and whilst a pale face, general lassitude, drowsiness, cold extremities, trembling hands, and a voracious appetite, are the indications of its existence in one, the brain is the first to give way in another, and insanity takes place."

In commenting on the prevalence of this vice among young people, he said:- "Would that I 


\section{Are We a Declining Race?}

could take its melancholy victims with me in my daily rounds, and could point out to them the awful consequences which they do but little suspect to be the result of its indulgence. I could show them those gifted by nature with high talents, and fitted to be an ornament and a benefit to society, sunk into such a state of physical and moral degradation as wrings the heart to witness, and still preserving with the last remnant of a mind gradually sinking into fatuity, the consciousness that their hopeless wretchedness is the just reward of their own misconduct."

Copland's "Dictionary of Medicine," Vol. II., p. 492, thus deals with "Exciting Causes of Insanity" :- "Whatever exhausts organic nervous power both predisposes to and directly occasions insanity. Many of these causes which thus affect nervous energy, favour congestion of the brain, and occasion disease of the vital organs, tending to disorder the functions of the brain sympathetically. Of these the most influential are masturbation and libertinism, or sexual excess, sensuality in all its forms, and inordinate indulgence in the use of intoxicating substances and stimulants. The baneful influence of the first of these causes is very much greater (in both sexes), than is usually supposed, and is, I believe, a growing evil. . . . It is even more prevalent in the fernale than in the male sex; and in the former it usually occasions various disorders in connection with the sexual organs-as leucorrhœa, displacement of the uturus, difficult or disordered or suppressed or profuse menstrua. 


\section{The Cause.}

tion, both regular and irregular hysteria, catalepsy, extasis, vertigo, and various states of disordered sensibility," etc., etc.

In Dr. R. P. Ritchie's "Frequent Causes of Insanity in Young Men " (I86r), we read:- " It is remarkable that writers on mental maladies pass over this section of mental affection with scarcely any allusion to the occasion of it-the vice of masturbation. I am also induced to submit the following observation to the profession from the fact that in IIg cases, which were recognised after admission in Bethnal House Asylum to be due to this melancholy cause, in only six was the true cause understood previous to admission, whilst the greater proportion of those cases in which the supposed cause was stated, were attributed to religion and overstudy. . . . There is little doubt that in this way a variety of obscure maladies are occasioned."

More attention is now being given to sexual abuses as being productive of insanity, and in some of our asylums patients are being specially treated for that phase of the disease.

Dr. Copland tells us that epilepsy precedes insanity from this cause, and either it, or general paralysis, often complicates the advanced progress of the mental disorder when thus occasioned.

Epilepsy being a functional disease of the nervous system, it is quite reasonable to suppose that in many cases it may be traced to the vice in question, although there are some who deny that this is the case. 


\section{Ave We a Declining Race?}

There is no other act which affects the nervous system so much as the one in question. Dr. Curschman ("Ziemsson's Cyclopedia") says :"It has been shown that the mischief does not consist so much in the loss of semen; by far the most important influence of sexual excess is upon the nervous system and upon nutrition. The act of copulation, and those mechanical irritations which have the like effect, are well known to be connected with a very intense excitement of the nervous system, which reaches its highest point just before ejeculation, and ends by the reflex discharge. Even in a state of health the act is followed by a notable degree of relaxation, but, if repeated often, the physiological effect becomes more enduring." This explains why masturbation should be considered as the principal cause of epilepsy.

Turning to Sir Thos. Watson's "Lectures on the Principles and Practice of Physic," Vol. II., p. 65I, we read :- "There are certain vices which are justly considered as influential and aggravating, and even in creating a disposition to epilepsy. Debauchery of all kinds, the habitual indulgence in intoxicating liquors, and, above all, the most powerful disposing cause of any, not congenital, is masturbation - a vice which it is painful and difficult even to allude to in this manner, and still more difficult to make the subject of enquiry with a patient. But there is too much reason to be certain that many cases of epilepsy owe their origin to this wretched and degrading habit; and more than one or two patients have voluntarily confessed to me their 


\section{The Cause.}

conviction that they had brought upon themselves the epileptic paroxysms for which they sought my advice."

Sir Thomas touched an important note here: " it is painful and difficult even to allude to." Of course it is painful. That is the reason why it has gained such a hold on the people. Masturbation would never have spread in this country, or in any other, to the present extent if medical men had done their duty as instructed citizens, and openly expounded the subject, and all its woes. It is only by public instruction that the evil can be checked, and the sooner open enquiry is commenced, the better it will be for humanity at large.

Dr. R. P. Ritchie says :- "Most confirmed insane epileptics indulge in the propensity." Dr. Ritchie was one of those who did not think epilepsy a result of the vice, as he thought that the vice succeeded, rather than preceded, the first epileptic attacks. I think it would be difficult for him, or anyone else, except the patient himself, to decide that question.

M. Christian was of the same opinion as Dr. Ritchie:-"Voici un épileptique ; il a des attaques plus fortes et plus fréquentes chaque fois qu'il se livre au coït ou à l'onanisme. Peutêtre même la première attaque a-t-elle éclaté á l'occasion du coït."

Dr. Ritchie seemed to think that the epilepsy preceded the vice, because he thought the vice to be of rarer occurrence with the public than is really the case; he said: "If it be said that the epilepsy in those so afflicted who practised the 


\section{Ave We a Declining Race?}

vicious habit in the asylum was due to it, then must the vice be of much more frequent occurrence than I have been able to trace."

"L'Epilepsie est sans contredit une des névroses sur la production ou l'aggravation de laquelle l'onanisme et l'excès vénériens de toute nature paraissent avoir la plus grande influence. - . Tous les auteurs sont d'accord sur ce point. Les anciens n'appelaient-ils pas le coït une 'epilepsia brevis'?

"Galien, Van Hers, Didier, Hoffman, Tissot, Haller, etc., et une foule d'autres ont rapporté le cas d'individus, qui avaient de véritables accès d'épilepsie chaque fois qu'ils se livraient à l'acte vénérien."-M. Mauriac, "Jaccoud Dictionnaire."

Evidently then, epilepsy was no mystery among the ancients. They did not allow Mrs. Grundy to influence them in the diagnosis of a disease; they were not to be deterred by any "scrupulosity of speech," they called a spade a spade, and recognised disease as the inevitable result of their own misconduct, and probably they were much better off in consequence.

I quote another French author, who recognises the discretion of the ancients.

"Pour beaucoup d'auteurs, cette affection parait avoir, chez la femme, la matrice pour origine, d'ou les noms d' epilepsia uterina, epilepsia $a b$ uturo, epilepsia genitale, comme on l'appelait autrefois. Si cela est vrai, rien n'est plus facile de comprendre comment les excès de coït et surtout de masturbation, en irritant les organes génitaux, peuvent à la longue, produire cette manifestation morbide. D'autre part dans son 


\section{The Cause.}

mode d'être, l'épilepsie sauf, sans durée indeterminée, il a beaucoup d'analogie avec le spasme vénérien que les anciens, frappés du fait nommaient 'Epilepsia brevis.' Enfin l'expérience ne permet pas de contester l'influence génitale sur la genèse de cette triste infirmeté et le rapprochement des crises. Quantités d'observations de savants estimés en font foi et sont trop connues pour être répétées ici. (Etude MédicoPhilosophque par le Docteur Pouillet."Epilepsie.")

Doubtless many people object to these subjects being dealt with in such plain language as that used by some of the French writers. But the importance of the subject is so great that it demands the plainest of plain language, and the courage to resist any attempt to taboo it. Note what was said by a writer in the principal medical organ of this country, only a few years ago, viz.: "The practice of masturbation has come to be regarded as an incurable evil, and the discussion of so unsavoury a subject is therefore tabooed."-(Lancet, September 23rd, I899.)

How in the name of reason is this evil to be overcome, if the subject is tabooed? Are our children to be left a prey to this curse of civilisation, simply because the subject is too unsavoury for us to discuss? Never let it be said that Englishmen allowed posterity to suffer such an enormity, for the paltry reason that they had not sufficient courage to deal with a distasteful subject.

The same writer tells us: "Still the habit is prevalent with a certain class of neurotics, and 


\section{Ave We a Declining Race?}

medical men, when they are brought face to face with such cases, feel helplessly at sea. In nineteen cases out of twenty, moral suasion is utterly useless."

It is evident that all medical men do not feel helplessly at sea, when brought face to face with it, or we should not have such valuable information as we are now able to obtain on the subject. Moral suasion is not useless. Very many people have been saved from lives of degradation and misery by a word of warning. Of the IIg cases of masturbatic lunatics, recorded by Dr. Ritchie, twenty recovered; therefore it is wrong to say that in nineteen cases out of twenty moral suasion is utterly useless.

Dr. Zimmerman gives a very good description of the beneficial results of moral suasion upon a young man under his charge.

“ Un épileptique, ágé de trente et un ans, était sujet, depuis plusieurs années, aux accès les plus violentes, avec complication de manie furiéuse, que nécessitait l'emploi frequent de la camisole de force. Le malheureux se precipitait avec une espèce de rage sur les infirmiers, et se serait brisé la tête contre les murs, si dans ces tristes circonstances, on ne s était rendre maître de sa personne, L'aveu, que me fit ce jeune homme, des relations qui existaient entre ses accès épileptiques et ses habitudes onanistiques, me fit diriger tous mes efforts vers sa moralisation. J'ai rarement obtenu dans la pratique si pénible des maladies mentales un resultat aussi consolant. Les accès diminuèrent de frequence et d'intensité avec la disparition progressive des funestes habitudes de 


\section{The Cause.}

ce malade. Les facultés intellectuelles reprirent une énergie nouvelle, et une épreuve de dix-huit mois me mit à même de constater une guérison, qui ne s'est pas démentie depuis six ans, et qui a non seulement permis à ce jeune homme d'être rendu à la liberté, mais de pouvoir remplir au dehors une fonction honorable. (Morel : "Mal. Ment." p. I76, quoted by M. Mauriac in "Jaccoud Dictionnaire.")

The imbecile does not often meet with such treatment as this young man received from Dr. Zimmerman, for few men possess the patience exhibited by him. These unfortunate people must be in a very degraded condition, and it must be a great strain on those who have to deal with them, but at the same time it is reasonable to conclude that if more dependence were placed upon moral treatment and less upon mechanical restraints, results would be more satisfactory.

Here is a specimen of the treatment meted out in some establishments :-

"Bromide of potassium given freely and continuously, takes away sexual desire and competence, but it produces great weakness and emaciation and cannot be continued for any length of time, therefore it is only a temporising remedy, and as far as we know there is no permanent cure. We have used Faradisation to the spine with benefit, but this also was temporising.

"Treatment is to prevent the habit, if possible, but no means have yet been devised by which this can be done. Blistering the prepuce we have found useful, but only for a time. Dr. 


\section{Ave We a Declining Race?}

Yellowlees rings the prepuce with silver wire as the snouts of swine are wired to prevent their routing. The plan is ingenious enough, and has been to a certain extent successful. In females, even, clytoridectomy has failed." - ("Psychological Medicine," Bucknill and Tuke).

Surely, if no other remedies than blistering, ringing, Faradisation, and doses of bromide of potassium can be applied, it would be better to put an end to such existences. As a matter of fact I have read of cases where bromide of potash has been used with fatal results. But we have seen that other means may be used ("me fit diriger tous mes efforts vers sa moralisation").

Numerous other authors mention epilepsy as a result of "l'abus des plaisirs de l'amour" :-

"Comme toutes les affections morales vives et soütenues, ils augmentent l'irritabilité cérébrale, et causent les vapeurs hystériques, l'hypachondrie, les chlorose, le folie, la demense, l'épilépsie." ("Nouveaux Elements d'hygiéne," par Charles Londe).

"Une troisième vérité, aussi bien prouvée que les excès vénériens jettent dans l'épilepsie." ("Traité de l'épilepsie," par A. M. K. Tissot).

"Masturbation, and other irritation of the external genitals, is by most authors, given as a cause of epilepsy."-(Lancet, July I4th, I900.)

Dr. J. H. McDougal, translator of Lallemand's "Treatise on Spermatorrhœa," gives an interesting description of three cases of epilepsy which were caused by this habit. But what need to draw further on the testimony of the medical 


\section{The Cause.}

profession? We have seen that they are mostly agreed that epilepsy is traceable to a large extent to sexual abuses; surely it is the duty of doctors in general to act in accordance with this large agreement! It would simplify matters very much, and perhaps lead to the stamping out of a very troublesome disease.

Epilepsy has been very much on the increase of late years, and any reasonable methods should be adopted to stay its progress. A word in season is worth a ton of medicine in these cases, and as regards the feelings of the victims it would be better to give them a slight shock, than to allow them to go on suffering in ignorance. In cases where the disease is hereditary, the patients themselves would not take offence at being questioned ; it is only the guilty who are afraid of the truth.

Other diseases are traceable to "l'abus des plaisirs de l'amour."

It has been mentioned already that that terrible scourge, consumption, is traceable to the same cause :-

"Hippocrate a déjà décrit la consomption dorsale, produite par l'abus des plaisirs de l'amour. Cette maladie nâit, dit-il, de la moelle de l'épine. - Toutes les fois qu'ils vont à la selle ou qu'ils urinent, ils perdent abondamment une liqueur séminale très liquide. Ils sont inhabiles à la génération, et ils sont souvent occupés de l'acte vénériens dans leurs songes. Les promenades, surtout dans les routes pénibles, les essoufflent, les affaiblissent, leur procurent des panenteurs de tête, et des bruits d'oreilles: 


\section{Ave We a Declining Race?}

enfin la fièvre lente termine leurs jours."("Dissertation on the Dangers of Onanism." A. Schwartz.) Hippocrates again in "De Glandulis," Foes. Q. 273, ascribes " tabes dorsales" to this vice.

"Premature or excessive sexual desires and indulgences, and still more the crime of self pollution, are the chief of the class of causes in producing tubercular phthisis, and several other maladies. . . . . . Several instances have occurred in my practice of persons having admitted this when afflicted with phthisis, or with any other of the maladies entailed by this vice, and they were conscious of the cause only when too late, and often when their minds and the powers of volition were too much weakened to resist the impulse to its commission. Even married people, who have become addicted to it previously to marriage, have continued it subsequently, as they have themselves confessed to me in several instances." - (Dr. Copland: "Dictionary of Medicine.")

"The loss of too much semen occasions lassitude, debilitates, and renders exercise difficult, it causes convulsions, emaciation, and pain in the membrane of the brain, it deadens the senses and particularly the sight, gives rise to a dorsal consumption, and various other disorders which are connected with these."-(Boerhaave: Onanisme, p. II.)

"Young people of either sex who devote themselves to lasciviousness destroy their health in dissipating those powers which were destined to bring their bodies to the greatest degree of 


\section{The Cause.}

vigour, and they at length fall into consumption."-(Ludwig, quoted by Tissot.)

"Too great a dissipation of the semen weakens the spring of all the solid parts, hence arises weakness, laziness, inertness, phthisis, dorsal consumption, numbness, a deprivation of the senses, stupidity, madness, fainting, and convulsions."-(Klookof, quoted by Tissot.)

Such a text as this last, nicely illuminated, framed and glazed, would make a valuable wedding present to young married people.

We have also Tissot's experience ; he knew of several young people who had been "atteints de consomption par la detestable manœuvre de la masturbation." Several other eminent men, such as M. Londe ("Effet de la Masturbation"); Charles Mauriac ("Jaccoud Dictionnaire "); Mr. Lewis ("Practical Essay on Tabes Dorsalis"); M. de Goster, Van Sweeten, and others, might be quoted to the same purpose.

I do not assert that everyone suffering from consumption is addicted to the vices in question, but I point to the fact that in many cases that fearful complaint is the direct result of indulgence.

"Cancer may develop in the kidneys, or the bladder, primarily, or involve these organs when commencing elsewhere. . . In women, however, the uterus is certainly liable to become the seat of cancer. From the recorded facts it would appear that there is some connection between such cancer and great functional activity in the genitalia. . . There seems no question that great sexual indulgence .... . 


\section{Ave We a Declining Race?}

has an influence over the production of cancer." (Milner Fothergill : "Diseases of Advanced and Sedentary Life," p. 77.)

The danger alone of producing this terrible complaint should be sufficient to cause alarm, and cause people to stop and think before giving way to indulgence.

"J'arrive à une maladie cruelle, dont une opération ou la mort est emplacablement l'issue et qui ne tue la femme le plus souvent, qu' après lui avoir fait endurer les plus vives souffrances. Quand je passe en revue mes souvenirs, il n'est pas en seul des nombreux cas de cancer utérin, confiés à mes soins, qui ne m'ait offert dans ces précédents des fraudes génitales.

"J'ai vu succomber ainsi des femmes à une àge encore peu avancé à une epoch de la vie que semble devoir être affranchie de ces sortes de dégénérescences. Pourquoi le mal venait-il ainsi anticiper sur les ravages du temps et bouleverser en quelques sorte les regles ordinaires. C'est que des fraudes effrenées avaient fatigué sans mesure, et usé prématurement les organes."(L. F. E. Bergeret: "Des Fraudes dans l'accomplissement des fonctions génératrices.")

Cancer is said to be rapidly on the increase. During the last 30 years its mortality has risen II7 per cent. Most incurable diseases, in fact, seem to have been on the increase during that period. According to Mr. J. F. Mills, who is responsible for a series of articles produced in the "Clarion" dealing with the physical degeneration of the masses, "The death rate from diabetes has risen from 29 to $8 \mathrm{I}$, a rise of $5^{2}$ per 


\section{The Cause.}

million, or 179 per cent. . . . The death rate from apoplexy has risen from 535 to 577 , an increase of 42 per million, or nearly 8 per cent.

Valvular disease of the heart from 235 to 360 an increase of 125 per million, or 60 per cent. Bright's Disease, from 222 to 278 , increase of 56 per million, or 20 per cent. Urinary diseases from 246 to 468 per million, or nearly doubled."

These are all very important diseases, and they are all affected by the vices alluded to. If they are incurable, they are at least preventable, and this shows where the efforts of medical men are misapplied. They have been so absorbed with the patching up of broken constitutions, that they have not allowed themselves sufficient time to study natural processes.

Those who have carried their enquiries into the study of generation, and the influence of the sexual act on the nervous system, have been more successful, and to them suffering is no longer the mystery that it is to those whose efforts have been expended in the patching up business, and they are now able to trace at least all degenerative diseases to over-indulgence in, or violations of, that act.

Dr. Curschman has told us, "by far the most important influence of sexual excess is upon the nervous system ; " therefore if the nervous system become disorganised, as it must with overindulgence, all organs of the body which are regulated by the nervous system, must fail more or less in the performance of their functions; the heart flags, the circulation of the blood is 


\section{Are We a Declining Race?}

sluggish, respiration is weak and therefore fails to purify the blood, the juices necessary for digestion are insufficient or of inferior quality and so the body is not properly nourished, and is subject to all kinds of disease. These conditions once acquired, it is easy to conceive how a body goes from bad to worse, until eventually it is unable to digest sufficient food to nourish it. "Nervous exhaustion, whatever its occasion, is a pathological degradation from which there is ever ready to spring up a plentiful crop of nerve ailments."-(Norman Kerr, M.D. : "Inebriety," p. I70.)

The heart is often the first organ to suffer from excessive draining of nerve force, and the first indications of disease are palpitations and shortness of breath. "Masturbators who have long been in the habit of giving way to that vice, especially complain of these symptoms, and often put them before all others. I might indeed give palpitation a prominent place among the results of sexual excess."-(Dr. Curschman : "Ziemsson's Cyclopedia," Vol VIII.)

Paraplegia, a peculiar form of spinal paralysis, in which voluntary motion is interrupted below the affected part of the spinal cord, "may be brought on by various causes, chiefly of an exhausting kind-by cold, by intemperance in drinking, by excessive sexual intercourse, or, still more surely, by self-abuse. I have had the last cause assigned to me voluntarily by patients themselves."-(Sir Thomas Watson.)

Chorea St. Vitti.- " All circumstances adapted to increase the excitability of the nervous system 


\section{The, Causse,}

at the period of sexual development are of great influence in producing this disease, such as premature excitement of the sexual passions." ("Ziemsson's Cyclopedia," Vol. XIV.)

Fautrel and Wendt speak especially of the consequences of self-abuse, practised in great excess previous to puberity. Fautrel's patients were all onanists.

Neurosis.- "We meet with spasm in the bladder in the hypochondriacal and hysterical and in very nervous persons in general, in whom mental excitement, excessive sexual indulgence, the incautious use of cantharides, occasionally also it is met with in connection with onanism and spermatorrhœa."-(Dr. Lebert : "Ziemsson's Cyclopedia," Vol. VIII.)

Hysteria.- " More frequently, however, does sexual over-irritation, particularly that induced by onanism, cause the disease."-(Dr. Jolly : "Ziemsson's Cyclopedia," Vol. XIV.)

Vaso Motor and Trophic Neurosis.- "Other writers have laid it to excess in venery or onanism." - (Dr. Eulenberg: "Ziemsson's," Vol. XIV.)

Tremor.- "As causative may also be mentioned, excess in venery and onanism."(Eulenberg.)

Atrophy of the Cerebrum. - Dr. Hitzig mentions the practice of onanism by a little girl of twelve suffering from the above affection.("Ziemsson's," Vol XII.)

Spermatorrhœea.- "Masturbation plays also a prominent part among the abuses of the genital organs. To speak plainly, the majority of those 


\section{$\therefore$ Ave IVe Declining Race?}

who suffer from spermatorrhœa either are, or have been masturbators. Either they have abandoned themselves to this vice alone, or they have indulged in it after giving way to ordinary sexual excess." - (Curschman : "Ziemsson's," Vol. VIII.)

General Failure.-“L'abus des plaisirs sexuels, dit Burdach, entraine non pas tant par la perte du sperme que par l'ebranlement du système nerveux, l'atonic des organes génitaux, le flux de semence, la paralysie, la faiblesse de la vessie, l'atrophie de la moelle épinière, le tremblement, les convulsions, l'hebétement des traits du visage, la surdite, les vertiges, l'affaiblissement de la mémoire, l'impossibilité de suivre les travaux qui demandent de la contention d'esprit, la perte des sentiments purement humains, l'idiotisme et la démence."

Now, I think I have quoted a sufficient number of authorities to show that almost all diseases are traceable, directly or indirectly, to sexual abuses. By abuses I mean not only the practice of masturbation, but also of ordinary sexual intercourse, so far as it is practised for mere pleasure ; the pathological effect on the system is identical in each case, the only difference being that the first is a solitary process, which can be indulged in at any time, and is therefore indulged in more frequently, and it is also practised at a much earlier age, long before ordinary intercourse is possible.

Nature is no respecter of legal documents, and the fact of persons getting married by law does not absolve them from the penalties inflicted by 


\section{The Cause.}

nature for violations of nature's law. It is as possible for a man to be profligate with one woman as with many, and it is possible for a woman to be wanton with her own husband.

"The only excuse for reproduction is improvement. Beasts merely propagate their kind, but the offspring of noble men and women will be superior to themselves, as their aspirations are. By their fruit ye shall know them.-(Thoreau: "Essay on Chastity and Sensuality.")

It is no use saying that man has discretionary powers and knows when to stop, while his capacity for discretion is rendered nil by the ignorance, on all sexual matters, in which he is brought up. He very seldom receives any instruction from his parents, and the subject is tabooed in ordinary conversation; at the same time, he is given to understand that matrimony is the only state worth striving after. The bulk of the current literature deals with the "tender passion " in one way or another, which tends to inflame his mind with amatory ideas, and there is little wonder that he gives unrestrained scope to his passions as soon as occasion offers. This in itself would be a sufficient cause for deterioration, but the case is far more serious.

If children and young people remained chaste until such time as it was deemed fit that they should marry, it would not be so bad, but under existing circumstances such a course is difficult. It is impossible to bring them up in absolute ignorance of sexual matters; therefore, unless they are cautioned that certain actions are wrong they are almost sure to become con- 


\section{Ave We a Declining Race?}

taminated, especially when they attend public schools, where children of all grades are brought together. Knowledge of the masturbatory act is now almost universal among school children, and steps to prevent its practice must be taken without loss of time. That is, if we wish to preserve the race.

"The sexual instinct buds in a boy. He does not know why; he cannot understand it at first. If much alone he stumbles by accident upon some unnatural means of gratification; if with other children, some one teaches him, and the boy becomes a victim. Babies and young children are sometimes abused by their nurses, and indeed there are so many routes leading to the same result, that it is wonderful how any one escapes, as some few certainly do.

"The only safe course is to assume that they all trifle more or less with themselves, or, at least, that they will do so unless precautions are used to guard them against it. The child must be recognised as a reasonable human being. $\mathrm{He}$ must go to bed at a regular hour, when, tired out with his day's duties, he will sleep at once, and he should not be allowed to lie in bed in the morning. He should not be left too much to himself, or with older boys, if it can be avoided, or with older girls." - ("Wood's Household Practice of Medicine, Hygiene and Surgery," Vol. II., p. 524).

This show's the necessity of watchfulness on the part of parents and teachers, and not only of watchfulness, but of instructions being given to children. The vice is of such a subtle nature 


\section{The Cause.}

that it might be practised by a child for some considerable time before the effects were sufficiently apparent to be noticed by a casual observer, and by that time irreparable damage may be done. The nervous system of a child is of such a delicate and complex nature, that if once disorganised, it is doubtful if it ever regains its perfect condition. Thus a child once given to this vice adopts a neurotic condition, which prevents it from ever attaining the perfect adult stage of development.

"Babies and young children are sometimes abused by their nurses." Many would, no doubt, be sceptical as to the possibility of young babies being contaminated with this evil, yet it is on record that babies of a very tender age have practised it themselves.

"Dr. Beevor showed a case of masturbation in an infant aged eleven months." - (Lancet, December 6th, 1890).

"En Novembre, 1873, un de nos distingués confrères d'Epernay, M. le docteur Palle, m'adressait une petite fille de I7 mois, qui avait contracté longtemps des habitudes d'onanisme." —(M. Pouillet : "Etude Médico-Philosophique.")

The cause of this condition, in these particular cases, it is unnecessary to discuss here; it is sufficient, to note, that such a condition is possible.

Before bringing this chapter to a close, I should like to refer briefly to another important feature of the result of "l'abus des plaisirs sexuels," its influence in the production of alcoholism. 


\section{Are We a Declining Race?}

I mentioned earlier that there was an undermining influence which seemed to be the cause of men giving way to drink. In some cases, shortly after marriage, the young man gradually adopted irregular habits, seemed to lose all self respect, frittered away his evenings at publichouses, sacrificed all powers of volition, all spontaneity and cheerfulness, all manliness, and eventually dwindled down into a confirmed sot. In some cases the wife was nearly as bad as the man. This condition was hardly to be explained as the result of alcohol alone, therefore I suspected that it was another evil result of sexual excess.

This was evidently not a generally accepted theory, for I had searched a good many temperance works without being able to find any allusions to it, until eventually I came across Dr. Norman Kerr's work on "Inebriety," and read as follows, p. I7I:- "A rarely acknowledged but significant cause exciting to inebriety, is sexual excess. In several cases I have been consulted; in one case by both husband and wife, with reference to inebriety developed unexpectedly within a few months after marriage, a careful scrutiny led to the diagnosis of the morbid antecedent, being prostration from excessive intercourse.

"These cases are amenable to treatment, and on an observation of the principal prescriptionmoderation in conjugal rights-recovery has been complete. Cases in advanced life have been under my care."

This brings the solution of another important 


\section{The Cause.}

problem within the precincts of probability. More than two thousand years ago it was stated by the Greek philosopher, Antisthenes: "The end of philosophy is to subdue the passions, and prepare for every condition of life." We must subjugate the passions before we can retrieve our position to-day. Temperance and chastity are the two virtues to be adopted, if we want to hold our own, and the sooner we recognise this fact the better it will be for the race. 


\section{CHAPTER VI. \\ The Conservation of Vitality.}

Reason's whole pleasure, all the joys of sense, Lie in three words-Health, Peace and Competence. But Health consists of Temperance alone, And Peace, O Virtue, Peace is all thy own.

Having placed the facts before the reader, it may seem unnecessary to prolong the discussion of a subject which must be distasteful to all-to none more so than myself. Yet, it is of the first and last importance that no stone be left unturned, to enlighten the public mind, however unthankful the task, and I would urge all to use their utmost endeavours to bring this matter to a successful issue.

We are in a much more serious condition than is generally supposed. If the physical decline of the race were merely a social problem, and had been brought about by depressing conditions of labour, and insufficient food, as so many authors seem to imagine, there would not be so much cause for alarm, as all these things might be, and no doubt will be, rectified in course of time, by improved social measures. But it is a moral problem, and one which cannot at present be aired at any time or in any place, as all things pertaining to the public welfare should be, and it is thus rendered all the more difficult of solution. 


\section{Are We a Declining Race?}

Before we can expect to make much headway, we must disabuse ourselves of the idea that we are so different, physiologically, from the lower animals, and that habits which would be decidedly detrimental to them, may be indulged in.with impunity by us. The idea that we are specially created beings has been the cause of much misunderstanding, through which the race has had to suffer.

Much harm has also been done, by well meaning writers, who denounce the greatest of human virtues, chastity, as an unnatural sin. It is unnecessary to enumerate instances, but such statements have been made and supported by medical men. Their views have been largely accepted, and the result is obvious.

"We emphatically condemn as a most pernicious doctrine, one calculated to work untold evil, and to foster the worst forms of vice, the theory that any injury whatever arises from a chaste celibacy. The organs are not weakened, nor their power lost, nor is there a tendency to spermatorrhœea, nor to congestions, nor to any one of those ills which certain vicious writers, and certain superficial and careless physicians have attributed to this state. No condition of life is more thoroughly consistent with perfect mental and physical vigour than absolute chastity."-(G. H. Napheys, M.D.: "The Transmission of Life.")

These are not the words of a man likely to pander to public opinion. He has spoken the truth in an age when it is often considered the better policy to vnraish one's sentences, to flatter 


\section{The Conservation of Vitality.}

the inclinations of an effete society. His statement is true. Our only hope of regaining a state of perfect health, perfect happiness, is by being chaste. Chastity is the conservation of that vital force which gives pleasure to life, and without which life is but a continuation of misery, disease, and suffering.

To be chaste is one of the most simple things in the world, until nature is once violated, when it becomes one of the most difficult, both mentally and physically. "La continence absolue est même relativement facile à ceux qui ne l'ont jamais enfreinte, car pour l'appareil genital, comme pour tous les autres appareils organiques, moins il est sollicité, moins il est impérieux."

Absence of this virtue has been the principal cause of the failure of civilisation, as it has been the cause of ruin of all great Empires-Egyptian, Persian, Greek, and Roman. The decline of the Roman Empire leaves little room for doubt as to its cause. The virtues of the Romans, "soon disappeared amid the immorality and decomposition that mark the closing years of the Republic and the dawn of the Empire. The stern simplicity of life which the censors had so zealously enforced, was exchanged for a luxury, which first appeared after the return of the Army of Manlius from Asia, increased to immense proportions after the almost simultaneous conquests of Carthage, Corinth, and Macedonia, received an additional stimulus from the example of Anthony, and at last, under the Empire, rose to excesses which the wildest Oriental orgies have never surpassed."-("History of 


\section{Ave We a Declining Race?}

European Morals," W. E. H. Lecky, M.A., Vol. I., p. I68).

It is not at all wonderful that under such conditions the Romans should have degenerated. Yet the effects of indulgence in these vices are so subtle, that irreparable harm is done before it becomes known. Gibbon says: "It was scarcely possible that the eyes of contemporaries should discover in the public felicity the latent causes of decay and corruption. The long peace, and the uniform government of the Romans, introduced a slow and secret poison into the vitals of the empire."-("Decline and Fall of the Roman Empire," Chap. II.)

Socrates spoke in a similar manner of the Athenians. In a conversation with Pericles, according to Xenophon, he said that too great security was attended with carelessness, luxury, and disobedience:- " After the Athenians saw themselves raised above the other Greeks they indulged themselves in indolence and became at length degenerate."

Whatever were the vices of the barbarian races of Europe, licentiousness does not appear to have been very conspicuous at that time, for they were all chaste as compared with the Romans, and it was the constant influx of new blood which kept the Romans from total collapse. "The diminutive stature of mankind was daily sinking below the old standard, and the Roman world was indeed peopled by a race of pigmies, when the fierce giants of the North broke in, and mended the puny breed."-(Gibbon.)

Amid the degradation of Rome, we meet with 


\section{The Conservation of Vitality.}

many noble efforts of reform by the philosophers of the time, but very little impression was made, superstition and vice being the supreme influences. "The criminal and frivolous pleasures of a decrepit civilisation left no thought for the immediate duties of the day, or the fearful trials of the morrow. Unbridled lust, and unblushing indecency, admitted no sanctity in the marriage tie. The rich and powerful established harems, in the recesses of which their wives lingered neglected and despised. The banquet, the theatre, and the circus exhausted what little strength and energy were left by domestic excesses. The poor aped the vices of the rich, and hideous depravity reigned supreme and invited the vengeance of Heaven. Such rare souls as remained pure amid the prevailing contamination would naturally take refuge in the convent of severe ascetics, and seek absolute seclusion from a world whose every touch was pollution."(H. C. Lea : "Historical Sketch of Sacerdotal Celibacy," p. 85.)

"Salvian must be heard in his denunciation against the licentiousness of the fifth century. -Among the chaste barbarians, we alone are unchaste; the very barbarians are shocked at our impurities. . . . We cherish, they shrink from, incontinence; we shrink from, they are enamoured of purity; fornication, which with them is a crime and a disgrace, with us is a glory.' "-( "History of Latin Christianity," Dean Milman, Vol. I., p. 383.)

The fact of these barbarians being chaste, as most authors seem to assert, speaks well for the 


\section{Ave We a Declining Race?}

principle of chastity, for they were known as very hardy races. They wore very scant clothing, their arms and legs being generally bare. Gibbon says:- "The barbarians of Germany, still faithful to the maxims of their ancestors, abhorred the confinement of walls, to which they applied the odious names of prisons and sepulchres." In the laws of Theodoric, the German, adultery was a capital crime, and the seducer of a virgin was forced to marry her, also to endow her with a fifth of his estate. With the Goths also, adultery was a capital crime, and irremissibly punished with death. Horace greatly commended the chastity of their women. Dean Milman quoting Salvian says:- "The Goths are treacherous but continent."

These hardy people originated in Scandinavia, and wore a garment of various colours reaching to the knee; their thighs, knees and legs were without any covering, their sleeves only covered the tops af their arms. Fancy us going outside the door without a top-coat on!

"The Saxons are savagely cruel, but remarkable for chastity."-(Milman. Vol. I., 383).

"There is, however, one feature in the manners of the ancient Saxons worthy of notice-the equality of rank which they allowed to women, and the chastity for which they were remarkable. . . The severest penalties were attached to every violation of female purity. Not only was adultery punished with a most horrid death, and a similar punishment awarded to the seducer, but even those familiarities be- 


\section{The Conservation of Vitality.}

tween the sexes which are generally esteemed innocent, were strictly prohibited to unmarried persons."-("Religion of Ancient Britons," Geo. Smith, F.A.S.)

Dean Milman again quotes Bishop Salvianus in support of the character of barbarians: "The Vandals, if Salvian is to be credited, maintained their severe virtue, not only in Spain, but under the burning sun, and amidst the utter depravity of African morals, and in that state of felicity, luxury and wealth which usually unmans the mind. They not only held in abomination the more odious and unnatural vices which had so deeply infected the habits of Greece and Rome, but all unlawful connexions with the female sex. . . . They enforced the marriage of public prostitutes, and enacted severe laws, against unchastity, thus compelling the Romans to be virtuous against their will."

And now, I think I have brought sufficient evidence in support of the argument that pain and suffering, which includes physical degeneracy, so far from being the result of a "rise in the scale of being," are the inevitable result of a fall. A fall, not in the old theological sense of the term, but that each person, of either sex, falls from a state of physical perfection and moral purity, on the surrender of virginity, and that the race has fallen through the effects of systematic indulgence in practices of a degrading nature.

This seems to me the only way of tackling the question; we might go on for another century with the application of palliatives, still 


\section{Ave We a Declining Race?}

being as far from the solution as ever, the situation in the meantime becoming more complicated. We must strike at the root, for real reform. Objections may be raised as to the advisability of publishing such information for the use of the general public; but my answer is that any vices not too vile to be practised, are not too vile to be denounced, and the more vile they are, the sooner the painful duty should be performed.

If we knew that a deadly cobra lay concealed in a beautiful garden that people were passing through, we should not rest content with the hope that the people might all pass through without disturbing the reptile. We should first caution the people, and then proceed to kill the snake. The vices in question possess all the subtlety of the snake, and are just as deadly in their sting, so that it is our bounden duty to caution people of their venomous nature.

Some may perhaps object, that the importance of the problem is exaggerated, and that chastity "so far from being a virtue, is invariably a great natural sin," and "the morality which upholds virginity as the type of womanly perfection is unnatural.") These statements have been made by persons who appeared to be thoroughly conscientious. Others are possessed with the idea that chastity has been the cause of many ailments, and for the reason of this confusion of ideas we have not far to seek.

Chastity and celibacy are terms which have frequently been used to mean the same thing; 


\section{The Conservation of Vitality.}

thus the confusion has arisen. Chastity means sexual purity, virginity ; whereas celibacy means merely an unmarried state. A person may be celibate, and yet be profligate; but it would be impossible for one to be profligate and still be chaste.

The clergy have, perhaps, had most to do with the calumny brought on the fair name of chastity, for, although pretending to lead lives of chastity, the clergy, as a body, were never chaste, and we read that as a class they were at times sunk far below the level of the laity. Says Lecky: "'The writers of the middle ages are full of accounts of nunneries that were like brothels, of the vast numbers of infanticides within their walls, and of the inveterate prevalence of incest among the clergy, which rendered it necessary again and again to issue the most stringent enactments that priests should not be permitted to live with their mothers and sisters." ("Hist. European Morals," vol. II., p. 330.)

Is it to be wondered at that consumption, cancer, and such diseases, should have found their way into such places, or that chastity should have borne the blame, for which debauchery and unnatural vices were really answerable? The apparently continent have ever been the greatest hindrance to the cause of chastity.

Objections will never alter facts. We find ourselves in a very awkward predicament, from which we must extricate ourselves. The only way is to put on a bold front, acknowledge our 


\section{Ave We a Declining Race?}

position, and make up our minds to live up to our light. Other nations have sunk under simi-. lar circumstances, and for many centuries have been unable to lift their heads. Let us prove equal to the occasion. We have the advantage of those that have gone before, for we are able to recognise where they failed, and are in a position to benefit by their experience.

There is really no mystery in the whole problem. The great mistake which has been made in all civilised communities is, that the importance of the sexual act has been ignored by the great majority. It has been surrounded with a halo of mystery, and free discussion of its properties has been discouraged, or counted as indecent. And to make matters worse young people are married without understanding the nature of it, and in their ignorance they have indulged in a lamentable dissipation of vitality. This injudicious behaviour would have been sufficient in itself, through long ages, to cause a certain amount of deterioration, but when we come to add the degrading vice of "chéiromanie," disaster is inevitable.

No person is so strong that he can afford to squander his nature, for it is the most important thing in life, "c'est la fleur du sang le plus pur."

We recognise this in the breeding of lower animals. These, although restricted by nature, require still further restraint by man, to bring them to perfection. For instance. The owner of an entire horse would never think of turning it loose into a field, in company with mares, during the rutting season. Count de Buffon 


\section{The Conservation of Vitality.}

tells us that in such case the stallion " in six weeks would do himself more harm than in a number of years with moderate exercise." How much more important is it then that moral restraint should be brought to bear upon our own species?

Mark well these few important words from Ruskin :- "Learn that every vicious habit and chronic disease communicates itself by descent ; and that by purity of birth the entire system of the human body and soul may be gradually elevated ; or, by recklessness of birth, degraded." As it is in posterity that we must depend principally for regeneration, so we must study our habits, remembering that according to our virtues or our vices so the race must wax or wane.

Whether we care to acknowledge it or not, the sexual act is for the purpose of propagation alone, and, when performed for the sake of mere pleasure it becomes a vice, and is attended with most disastrous results.

This, then, is the solution to the great problem of the physical deterioration of the masses. We must lay bare the causes in the sight of the people, and, depend upon it, the dissipation of our vitality will cease, and its conservation begin.

"The ENd of Life is, NOT to GET, BUT to BE." -Momerie. 


\section{PRINCIPAL AUTHORITIES QUOTED.}

Major-Gen. Sir Frederick Maurice, K.C.B.-Contemporary Review, Jan., 1903.

London County Council Statistics for the Ten Years Ending March 3Ist, Igor. " Lunacy."

Sir W. C. ElLIS- " Treatise on Insanity."

Dr. R. P. RitchiE-" Frequent Causes of Insanity Amongst Young Men."

Sir JoHN SinClaIR - "Statistics."

Mr. EASTON-" On Longevity."

Mr. WhITEHURST-"Enquiry into the Origin and Strata of the Earth."

RAPIN DE THOGRAS- " History of England."

Mr. Kay RoBinson -Nineteenth Century, May, 1883.

Dr. Lister-Address to Saturday Hospital Fund Meeting at Mansion House, April 25th, 1903.

Mr. H. Rippon Seymour-Westminster Review, Sept., I903.

Dr. NORMAN KERR-“"Inebriety."

Mr. Lewis Morgan - "Ancient Society."

Pro. T. H. HuxleY - "Evolution and Ethics."

Dr. BIRCH_-"History of Egypt."

Pro. Rawlinson-" "History of Ancient Egypt."

M. Westermarck - "History of Human Marriage."

Dr. J. H. GRAY - " China."

Mr. C. Darwin- " Origin of Species."

Capt. J. Соoк- " Voyages."

Mr. R. BRough Smyth-"The Aborigines of Victoria."

Mr. WinWOod READE-" Savage Africa."

Rev. J. SHORTER - "Kaffirs of Natal."

Mr. J. BARROw- "Travels in Southern Africa."

Bardolph Seemann, Ph.D., F.L.S., F.R.G.S.- "Vita: an Account of a Government Commission to the Fijian Islands."

Extracts from Report of the Government Commission Appointed to Inquire into Decrease of Native Population, 1893, Suva, Fiji.

Lord StANMORE-Daily Chronicle, June Ist, I894.

Mr. J. Stuart Mill_-" Principles of Political Economy."

M. MAURIAC-“Jaccoud Dictionnaire de Médecin et de Chirurgée."

M. Christian-" "Dictionnaire Encyclopedique des Sciences Medicales."

M. Aloyce SchWARTZ- "Dissertation sur les Dangers de l'Onanisme." 


\section{Principal Authorities Quoted.}

M. Tissot-"Traité de l'Onanisme." John Allen Godfrey- "The Science of Sex." DANIEl DeFOE- "Conjugal Lewdness."

Lancet.

Dr. J. Copland- "J. Copland's Dictionary of Medicine."

Dr. Curss:hman - "Ziemsson's Cyclopedia."

Sir Thos. Watson-" "Lectures on the Principles and Practice of Physic."

Dr. Pouillet- "Etude Médico-Philosophique."

Bucknill and Tuke-" Psychological Medicine."

M. Charles Londe-“Nouveaux Elements d'Hygiéne."

Mons. A. M. K. Tissot-" Traité de l'Epilepsie."

Dr. J. H. McDougaL-Translator of "Lallemand's Treatise on Spermatorrhœa."

Mr. Lewis - "Practical Treatise on Tabes Dorsalis."

Dr. BoerhaAve-“"Onanisme."

Mr. Miller Fothergill- "Diseases of Advanced and Sedentary Life."

L. F. E. Bergeret - "Des Fraudes" dans l'Accomplissement des Fonctions Génératrices."

H. D. Thoreau - "Essay on Chastity and Sensuality."

Dr. Woop-"Wood's Household Practice of Medicine, Hygiene and Surgery."

Dr. G. H. Napheys - "The Transmission of Life."

Mr. W. H. E. Lecky, M.A.- "History of European Morals." Mr. E. GibBon - "Decline and Fall of the Roman Empire."

Mr. H. C. LEA- "Historical Sketch of Sacerdotal Celibacy." Dean Milman-" History of Latin Christianity."

Mr. Geo. Smith, F.A.S.- "Religion of the Ancient Britons." Mr. John Ruskin- "Modern Painters." 


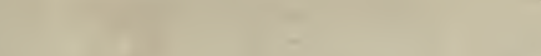
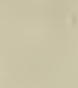

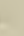

$+$

4

,


RETURN TO the circulation desk of any University of California Library

$$
\text { or to the }
$$

NORTHERN REGIONAL LIBRARY FACILITY

Bldg. 400, Richmond Field Station

University of California

Richmond, CA 94804-4698

ALL BOOKS MAY BE RECALLED AFTER 7 DAYS

- 2-month loans may be renewed by calling (510) 642-6753

- 1-year loans may be recharged by bringing books to NRLF

- Renewals and recharges may be made 4 days prior to due date.

DUE AS STAMPED BELOW

SEP 282001 
YA 00881 
Crown 8vo., Cloth Gilt. 2s. 6d. Net.

\section{IDEALS OF LIFE AND CITIZENSHIP.}

SELECT Pleces FROM THE Best AdTH RS, CHUSEN BY

\section{I. MAURICE.}

The wish of the Editor has been to cultivate in theminds of elder children, and those just growing up into manhoud and womanhood, the belief in the possibility of peaceful heroism, to show that the power of sympathy and courtesy, the courageous endurance of suffering in the peaceful assertion of good causes, and the struggle after the higher thoughts and feelings, are, at least, as necessary to the formation of good citizens, and in consequence, of great nations, as any of those more showy qualities now so generally admired.

"We can recommend this excellent book."-Literary World.

"A finely conceived and eminently salutary book."-Manchester Guardian.

"The ideals that should guide the citizens of a free state." - The Churchwoman.

LONDON :

FRANCIS RIDDELI. HENDERSON, TOLSTOY DEPOT, 26, PATERNOSTER SQUARE, E.C. 